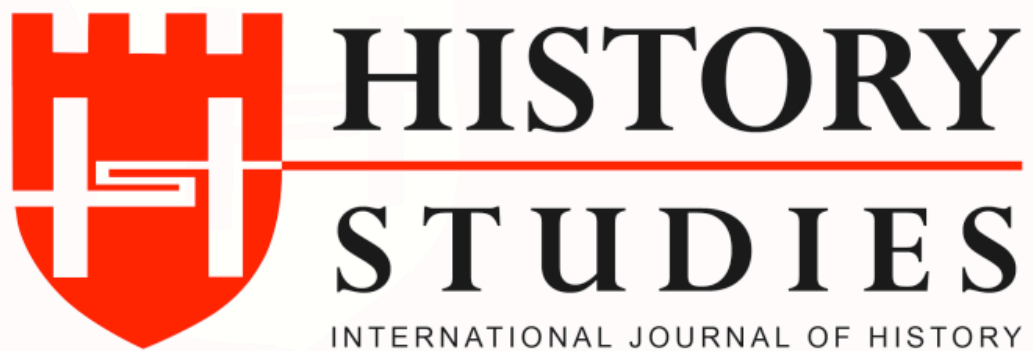

\author{
ISSN: 13094173 (Online) 1309 - 4688 (Print) \\ Volume 11 Issue 5, October 2019 \\ DOI Number: 10.9737/hist.2019.773 \\ Araştırma Makalesi
}

Makalenin Geliş Tarihi: 22.05.2019 Kabul Tarihi: 11.07.2019

Atıf Künyesi: Sedef Bulut - Ceyhun Öğreten, “Türk-Sovyet İlişkilerinde Yol Ayrımı: 1925 Türk-Sovyet Saldırmazlık Paktının İptali ve Amerikan Basını", History Studies, 11/5, Ekim 2019, s. 1457-1489.

\title{
Türk-Sovyet İlişkilerinde Yol Ayrımı: 1925 Türk-Sovyet Saldırmazlık Paktının İptali ve Amerikan Basını
}

\author{
The Breakdown of Turkish-Soviet Relations: The Cancellation of The 1925 Turkish- \\ Soviet Non-Aggression Pact And American Press
}

\author{
Dr. Sedef Bulut - Ceyhun Öğreten \\ ORCID No: 0000-0002-5525-584X-0000-0003-3118-9304 \\ Ankara Üniversitesi
}

\begin{abstract}
Öz:
1921 Moskova Antlaşması ile 17 Aralık 1925 Dostluk ve Tarafsızlık (Saldırmazlık) Paktı, TürkSovyet ilişkilerinde önemli kilometre taşlarındandır. Türkiye ve Sovyet Rusya, karşıllklı dış politikalarını II. Dünya Savaşı sonlarına kadar 1925 Saldırmazlık Paktı temeline oturtmuşlardır. Ancak iki ülke arasındaki ilişkiler, 1936'daki Montreux Konferansı görüşmelerinde kırılmaya başlamış, Sovyetlerin, 1939 yılında güvenliğini bahane göstererek Boğazlar Statüsünde değişiklik isteğinde bulunması ise bu kırılmanın daha da belirginleşmesine neden olmuştur. Bu durum, Türkiye, İngiltere ve Fransa arasında Karşılıklı Yardım Antlaşması'nın (Üçlü Pakt) imzalamasını kolaylaştırmıştır. Savaş boyunca denge politikasını izleyen Türkiye, Müttefiklerin ve Sovyetlerin baskılarına rağmen savaşın dışında kalmayı başarmış ancak bu durum savaşın galip tarafında yer alan Sovyetlerin, Türkiye ile ilişkilerine olumsuz yansımıştır. Bunun bir sonucu olarak Sovyetler, 19 Mart 1945 tarihinde, 1925 Dostluk ve Tarafsızlık (Saldırmazlık) Paktı Antlaşması'nı uzatmayacağını bildirmiş ve 1921 Moskova Antlaşması'na aykırı olarak da, Türkiye'den Kars ve Ardahan illerini istemiştir. Sovyetlerin bu taleplerine kendi çabaları ile karşılık veren Türkiye, savaş olasıllı̆̆ belirince Amerika önderliğindeki Batı Blok'una yakınlaşmışıır. Bu çalışmada, Türkiye ile Sovyetler arasında imzalanan Saldırmazlık Paktının iptali meselesi ile Sovyetlerin, Boğazlar ve arazi terki konularındaki taleplerinin Amerikan kamuoyunda nasıl karşılık bulduğu sorusu, ABD basını üzerinden incelenecektir.
\end{abstract}

Anahtar kelimeler: Sovyetler Birliği, Türkiye, Saldırmazlık Paktı, Boğazlar, Montreux, Amerikan Kamuoyu, Amerikan Basinı.

\begin{abstract}
:
1921 Moscow Treaty and the Treaty of Friendship and Neutrality (Non-Aggression) Pact signed on 17 December 1925 are important turning points in Turkish-Soviet relations. Turkey and the Soviet Union have sat their mutual foreign policy on the Aggression Pact dated 1925 until the end of World War II. In the meetings of the Montreux Conference in 1936, there were some disagreement between two countries. In 1939, Soviets, by using a excuse for the security, had demanded a change in the Status of the Straits that was a serious breaking point of the relations between two countries. This incident facilitated the signing of Mutual Assistance Treaty between Turkey, Britain and France (Tripartite Pact). During the war, following the policy of balance Turkey, despite pressure from the Allies and the Soviet war but has managed to stay out of the battle victorious side in this case located
\end{abstract}


in the Soviet Union were affected negatively the relations with Turkey. As a result of this The Soviets stated that the Treaty of Friendship and Neutrality (Non-Aggression) Pact in 1925 would not be extended on 19 March 1945 and in contradiction with the 1921 Treaty of Moscow, requested the provinces of Kars and Ardahan. Turkey responded to these demands of the Soviets by his own efforts. When the possibility of war was determined, Turkey got close to the western-block led by United States. In this study, the issue of the cancellation of the Turkey-Soviet Non-aggression Pact and the question of how the demands of the Soviets on the Straits and transfer of land were will be examined. In this context, US public opinion and the effects of these incidents in the US press will also be discussed.

Keywords: The Soviet Union, Turkey, Non-Aggression Pact, The Straits, Montreux, American Public Opinion, American Press.

\section{Giriş}

Milli Mücadele Dönemi Türk dış politikasının en dikkat çekici safhasını Türkiye-Sovyet Rusya ittifakı teşkil etmektedir. Ankara'da henüz Türkiye Büyük Millet Meclisi (TBMM) açılmadan önce Sovyetler, Türkiye ile yakından ilgilenmeye başlamış, -geleceğe yönelik politikaları doğrultusunda- Anadolu'da başlayan Milli Mücadele hareketini yakından takip etmiştir. Bu durumu iyi analiz eden Mustafa Kemal Paşa, Sovyet Rusya'ya bir mektup göndermiştir. 26 Nisan 1920 tarihli bu mektupta, emperyalizme karş1 birlikte hareket edilmesini istemiştir. ${ }^{1}$ Sovyet Dışişleri Bakanı Çiçerin, 3 Haziran 1920'de bu mektuba cevap vermiştir. ${ }^{2}$ Çiçerin'in mektubunda Mustafa Kemal Paşa'nın önerisinin memnunlukla karşılandığı iki devlet arasında diplomatik ve konsolosluk ilişkilerinin kurulması uygun bulunmuştur. ${ }^{3}$ Mektupta bir ittifaktan bahsedilmese bile iki hükümet arasında diplomatik ilişkilerin bu vesile ile başladığını söylemek mümkündür.

TBMM ile Sovyet Rusya arasındaki dostluk anlaşması, para ve silah yardımı konularına yönelik görüşmeler Hariciye Vekili Bekir Sami Bey başkanlığındaki heyetin Moskova'ya varmasından sonra başlamıştır. Türk heyeti, Moskova'da bulunduğu süre zarfinda Lenin ve Çiçerin ile görüşmüş, Türkiye'ye yardım yapılması yönünde görüş oluşmasına rağmen Türk yetkililerin Ermeni yolunun açılması talebi dostluk anlaşması girişimlerini sonuçsuz bırakmıştır. ${ }^{4}$ TBMM'nin Ermenilere karşı kazandığı başarılar ve ilerlemeler üzerine Sovyetlerin tavrı değişmiş ve TBMM ile Ermenistan arasında imzalanan 3 Aralık 1920 tarihli Gümrü Anlaşması bir dönüm noktası olmuştur. ${ }^{5}$

10 Ağustos 1920'de Sevr Antlaşması'nın İstanbul Hükümeti ile imzalanmasının ardından, işgalcilere karşı Anadolu'da bağımsızlık savaşı başlamış, 29 Kasım 1920'de Dışişleri Bakanı Çiçerin'e telgraf gönderen Mustafa Kemal Paşa, "Batılı emperyalistlere karşı yakın ittifak" kurulmasını istemiştir. Diğer yandan Moskova Büyükelçiliğine atanan Ali Fuat Paşa da, 26 Şubat 1921 'de siyasi anlaşma görüşmelerini başlatmıştır. İttifak meselesi gündeme gelse de bu ittifak Sovyet çekinceleri yüzünden mümkün olamamıştır. Moskova'da bulunan Afganistan heyeti ile 1 Mart 1921'de dostluk anlaşması imzalanırken ${ }^{6}$ Kurtuluş Savaşında TBMM'nin diş politikadaki ilk başarılarından birini simgeleyen Moskova Antlaşması, 16 Mart 1921 tarihinde "1921 Türkiye - Sovyet Rusya Dostluk ve Kardeşlik Antlaşması" adı altında imzalanmıştır.

\footnotetext{
${ }^{1}$ Ayrıntılı bilgi için Bkz. Semiyon İvanoviç Aralov, Bir Sovyet Diplomatının Türkiye Hatıraları, Cumhuriyet Yayınları, İstanbul, 1997, s. 21.

${ }^{2}$ Kazım Karabekir, İstiklal Harbimiz, Yapı Kredi Yayınları, İstanbul, 2014 s. 875-876.

${ }^{3}$ Aralov, age., 22.

${ }^{4}$ Ali Fuat Cebesoy, Moskova Hâtıraları (21.11.1920-2.6.1922), Temel Yayınları, İstanbul, 2002, s. 59-71.

${ }^{5}$ Fahir Armaoğlu, 20. yy Siyasi Tarihi (1914-1918), İş Bankası Yayınları, Ankara, 1993, s.308-312.

6 Age., s.312-313.

${ }^{7}$ Salahi R. Sonyel, Türk Kurtuluş Savaşı ve Dış Politika II, Türk Tarih Kurumu Yayınları, Ankara, 2010, s. 56.
} 
İtilaf devletleri karşısında TBMM'ye önemli bir güç katan bu Dostluk Antlaşması ile Sovyetler, Misak-1 Milli sınırlarını tanıdığı gibi, Kars, Ardahan ve Artvin Türkiye'ye, Batum ise Gürcistan'a bırakılmıştır. ${ }^{8}$ Antlaşmada, Boğazlar statüsünün Türkiye yararına düzenleneceği, Ruslara verilen kapitülasyonların kaldırılacağı ${ }^{9}$ ve ayrıca Sovyetlerin, cephane ve para yardımında bulunacağı hüküm altına alınmıştır. ${ }^{10}$

Türk-Sovyet ilişkileri özelikle Sakarya Savaşı'nın ardından iyice gelişmeye başlamıştır. 26 Eylül 1921 tarihinde, Kars'ta, Sovyetler, Türkiye ve üç Güney Kafkasya ülkesi Ermenistan, Gürcistan ve Azerbaycan ile görüşmeler başlamış ve 15 Ekim 1921'de içerik açısından Moskova Antlaşması'na benzeyen bir dostluk anlaşması imzalanmıştır. ${ }^{11}$ Zaten Moskova Antlaşması'nın 15'inci maddesi ile Ruslar hem Moskova Antlaşması'nı hem de Türkiye'nin doğu sınırlarını Kafkas Cumhuriyetlerine kabul ettirmeyi taahhüt etmişlerdir. ${ }^{12}$ En önemlisi Kars Antlaşması ile hem Rusya'dan gelen yardımların önü açılmış hem de Türkiye'nin doğu sınırları, söz konusu devletler tarafından tanınmıştır. ${ }^{13}$

Sovyetlerle yapılan tüm anlaşmalar ve yardımlara rağmen iki hükümet arasındaki ilişkiler hiçbir zaman güvenli bir dostluk şekline dönüşememiştir. Bunun başlica sebebi ise "Komünizm" meselesi olmuştur. Mustafa Kemal Paşa, Rusya ile ortak menfaatler doğrultusunda bir ittifak ilişkisine ne kadar sıcak baktıysa, Komünizmin Rusya tarafindan Anadolu'ya sokulması meselesine ise o ölçüde karşı çıkmıştır. ${ }^{14}$

Türk-Sovyet ilişkileri, Cumhuriyetin ilanından sonra öncelikli olarak dış politikada Lozan Antlaşması'nın çözümleyemediği meseleler çerçevesinde şekillenmiştir. Bir yandan, Musul meselesinin Türkiye aleyhine sonuçlanması dolayısıyla İngiltere ile yaşanan gerginlik, diğer yandan Şeyh Sait Ayaklanması Türkiye'yi hem içeride hem de dışarıda çok zor bir duruma düşürmüştür. Batılı devletler ile olan meseleleri çözmek konusunda zorluk yaşayan Türkiye, bu süreçte Sovyet Rusya'yı bir dayanak olarak görmüştür. Sovyet Rusya'nın da Batılı devletler tarafından dışlanması ve aynı zamanda bir çember içine alınmaya çalışılması ${ }^{15}$ iki ülkeyi tekrar bir menfaat birliğine yönlendirmiştir.

Almanya'nın Fransa ile yakınlaşarak doğu sınırında hareket serbestliği kazanması Rusya’yı tedirgin etmiştir. İç siyasette bir yandan lider Lenin'in ölümünden sonra ortaya çıkan iktidar mücadeleleri ile boğuşan Sovyet Hükümetini, Batılllar ile Almanya'yı bir araya getiren 1 Aralık 1925 tarihli Locarno Güvenlik Sistemi ${ }^{16}$ ise iyice telaşlandırmıştır. Bu süreçte 1921 tarihli Moskova Antlaşması'nın geliştirilerek, ilişkileri düzenleyecek bir anlaşma yapma önerisi ilk olarak Eylül 1924 'te Rusya'dan gelmiştir. Ancak gerek Rusya ile İngiltere arasında devam

\footnotetext{
${ }^{8}$ Sabahattin Selek, Anadolu İhtilali, Burçak Yayınevi, İstanbul, 1968, s. 557.

${ }^{9}$ Saime Yüceer, Milli Mücadele Yıllarında Ankara-Moskova İlişkileri, Sentez Yayınları, İstanbul, 2016, s. 145.

${ }^{10}$ Selahattin Tansel, Mondros 'tan Mudanya 'ya Kadar C.IV., Milli Eğitim Bakanlığı Yayınları, İstanbul, 1991, s. 72.

${ }^{11}$ Aralov, age., s. 42.

12 Erel Tellal, "SSCB’yle İlişkiler”, Türk Dış Politikası, Ed. Baskın Oran, İletişim Yayınları, İstanbul, 2009, s. 174175 .

${ }^{13}$ Adı geçen antlaşmalar hakkında ayrıntılı bilgi için Bkz., İsmail Soysal, Tarihçeleri ve Açılamaları ile Birlikte Türkiye'nin Siyasal Antlaşmaları C.I (1920-1945), Türk Tarih Kurumu Yayınları, Ankara, 2000.

${ }^{14}$ Armaoğlu, age., s. 314.

15 Salim Gökçen, "Ankara-Moskova İlişkilerinin Gelişimi ve 1925 Dostluk ve Saldırmazlık Antlaşması”, Uluslararası Karadeniz Incelemeleri Dergisi, 2007, s.123.

${ }^{16}$ Locarno Anlaşmaları: 1'inci Dünya Savaşı sonrası Batı Avrupa'da barışın korunmasını korumak maksadıyla Almanya, Belçika, Fransa, İngiltere ve İtalya arasında 1 Aralık 1925 tarihinde Londra'da imzalanan üç antlaşmadır. (Mustafa Aydın, "İkinci Dünya Savaşı ve Türkiye", Türk Dış Politikası, Ed. Baskın Oran, İletişim Yayıncılık, İstanbul, 2009, s. 403.)
}

\section{History Studies}


eden müzakereler gerekse de her iki ülkenin mücadele ettiği iç ve dış meseleler yüzünden bu anlaşma hemen imzalanmamıştır. ${ }^{17}$

Sovyetlerin, Birinci Dünya Savaşı sonrası 'kapitalist ülkelerle Alman yakınlaşmasını engelleme' politikası Locarno Antlaşmaları ile sona erince ${ }^{18}$ Sovyetler ve Türkiye, Milletler Cemiyeti'nin 'Musul Sorunu' kararından hemen sonra 17 Aralık 1925 tarihinde "1925 TürkiyeSovyetler Birliği Dostluk ve Tarafsızlık (Saldırmazlık) Antlaşması ile Uzatma Protokolleri”ni imzalamıştır. ${ }^{19}$

Söz konusu Saldırmazlık Antlaşması'nın 1'inci maddesinde, taraflardan birine üçüncü devletçe yapılacak askeri bir teşebbüste diğer akit tarafın tarafsız kalacağı, 2'nci maddesinde, tarafların birbirlerine saldırmayacakları, birbirlerinin aleyhine karşı oluşturulacak anlaşma ve ittifaklara girmeyeceklerini kabul etmişlerdir. ${ }^{20}$ Antlaşmanın, üç yıl yürürlükte kalacağı, iptal talebi olmaması durumunda bir yıl daha uzayacağı belirtilmiştir. ${ }^{21}$ Sovyet Dışişleri Bakanı Çiçerin, Antlaşmanın imzalandığı gün Dışsişleri Bakanı Dr. Tevfik Rüştü Bey’e verdiği özel bir mektup ile Türkiye'nin üçüncü bir devletle savaşa girmesi durumunda Moskova Antlaşması'nın temel alınacağını söylemiştir. ${ }^{22} 17$ Aralık 1929 tarihinde sona erecek olan Antlaşma; önce iki yıl, ${ }^{23} 1931$ senesinde yeni bir protokol eklenmesi ile beş y1l ${ }^{24}$ ve 7 Kasım 1935 tarihinde ise on yıl süre ile son defa uzatılmıştır. ${ }^{25}$

Yaklaşık 20 yıl yürürlükte kalan Saldırmazlık Paktı ile devam eden Türk-Sovyet dostluğu, İkinci Dünya Savaşı sürecinde oldukça zarar görmüş, savaşın sonlarına doğru ise Sovyet Rusya'nın tehditkâr politikalarıyla birlikte Paktın iptali meselesi gündeme gelmiştir. Söz konusu Paktın nasıl iptal edildiği ve Batı blokuna yaklaşan Türkiye'nin politikalarının, ABD kamuoyunda nasıl karşılık bulduğu meselesi bu çalışmanın ana eksenini oluşturmaktadır. Beyaz Saray'ın sözcüsü konumundaki The Evening Star, Demokrat The Key West Citizen, Cumhuriyetçi kanada yakın The Midnal Journal, bağımsız The Wilmington Morning Star, Rusya'ya yakınlığıyla bilinen Henderson Daily Dispatch, gazetelerinin yanı sıra The New York Times gazetesindeki yazılar ve makaleler de bu çalışma kapsamında değerlendirilmiştir. Aynı zamanda Amerikan Dışişleri Belgelerinden (FRUS) yararlanılmıştır.

\section{II. Dünya Savaşına Giden Süreçte Türk-Sovyet İlişkileri ve Amerikan Basını}

Türk Hükümeti, 1933'ten sonra Lozan Boğazlar Sözleşmesi'nin günün koşullarına uyarlanarak, Türkiye'nin güvenliğinin sağlanması gerekçesi ile çeşitli girişimlerde bulunmuştur. Özellikle 1935 yılından sonra İtalya'nın Habeşistan'ı işgali ile Milletler Cemiyeti prensiplerinin çiğnenmesi, aynı zamanda Alman silahlı birliklerinin Ren askersizleştirilmiş

\footnotetext{
${ }^{17}$ Gökçen, agm, s.124

${ }^{18}$ Mehmet Gönlübol, ve Cem Sar, “1919-1938 Yılları Arasında Türk Dış Politikası”, Ed. Mehmet Gönlübol, Olaylarla Türk Dış Politikası 1919-1995, Siyasal Kitabevi, Ankara, 1996, s. 77.

${ }^{19}$ Ayrıntılı bilgi için Bkz.: İsmail Soysal, age, s. 272.

${ }^{20}$ Mehmet Gönlübol, ve Cemal Sar, Atatürk ve Türkiye'nin Dış Politikası (1919-1938), Atatürk Araştırma Merkezi

Yayınları, Ankara, 2013, s. 85.

${ }^{21}$ Soysal, age., s. 276-278.

22 Ayrıntılı bilgi için Bkz., İsmail Soysal, “1925 Türk Sovyet Saldırmazlık Paktı'na Ekli Gizli Kalmış Bir Belge: Çiçerin'in Mektubu”, IX. Türk Tarih Kongresi, Eylül 1981.

${ }_{23}$ Rifat Uçarol, Siyasi Tarih 1789-2014, Der Yayınları, İstanbul, 2015, s. 690-692.

${ }^{24}$ Ayrıntılı bilgi için Bkz.: TBMM, Zabıt Ceridesi, 4. Dönem, 1. Yasama Yı11, Cilt 3, 22.7.1931.

${ }^{25}$ Ayrıntılı bilgi için Bkz.: TBMM, Zabıt Ceridesi, 5. Dönem, 2. Yasama Yılı, Cilt 7, 20.12.1935.
} 
bölgesini işgal etmesi gibi uluslararası kuralları altüst eden eylemler Türkiye'nin taleplerinin yerine getirilmesinde etkin rol oynamıştır. ${ }^{26}$

Türkiye Sovyetler Birliği ile görüşmelerde bulunduktan sonra 11 Nisan 1936 tarihinde Lozan Konferansı'na katılmış olan bütün ülkelere bir nota göndermiştir. Türkiye bu nota ile güvenlik zafiyetine dikkat çekerek, egemenlik hakkının korunması için mevcut durumun değişmesi yönünde değişiklik talep etmiştir. 14 Nisan 1936 tarihli notası ile ilk cevap veren ülke Sovyet Rusya olmuştur. ${ }^{27}$ Sovyetler, Türk notasına kendi lehine değişiklikler yapılabileceği umuduyla olumlu cevap vermiştir. Diğer taraf devletlerin de olumlu yaklaşmasi neticesinde Montreux Konferansı, 22 Haziran 1936 tarihinde İtalya hariç dokuz devletin katılımıyla başlamıştır. ${ }^{28}$

Türkiye, Konferansta, Karadeniz'e kıyıdaş olmayan devletlerin savaş gemilerine tonaj sınırı getirmeyi, bu denizde geçirecekleri süreyi kısıtlamayı, yakın savaş tehdidi durumunda savaş gemilerinin geçiş inisiyatifini ele geçirmeyi ve Boğazlardan geçecek Karadeniz'e kıyıdaş devletlerin savaş gemilerine tonaj sınırı getirmeyi teklif etmiştir. Ayrıca, Boğazlar Komisyonunu ve silahsızlandırma ile ilgili hükümleri kaldırmayı amaçlamıştır. ${ }^{29}$ Sovyetler ise Boğazların Karadeniz'e kıyıdaş olmayan devletlerin savaş gemilerine kapatılmasını ve kıyıdaş savaş gemilerine serbest geçiş verilmesini istemiştir. ${ }^{30}$ Görüşmeler sonucunda 20 Temmuz 1936 tarihinde Montreux Boğazlar Sözleşmesi imzalanmış ve Türkiye Boğazlar üzerindeki tam egemenliğini kabul ettirmiştir. ${ }^{31}$

Türkiye'nin, İngiltere ve Fransa ile Yardım Deklarasyonu konusunda anlaşması, Sovyetlerin ise 23 Ağustos 1939'da Almanya ile Saldırmazlık Paktı imzalaması Avrupa'da dengeleri derinden etkilemiştir. ${ }^{32} \mathrm{Bu}$ paktın imzasından kısa bir süre önce Dışişleri Bakanı Şükrü Saraçoğlu, Ankara'daki Sovyet Büyükelçisi tarafından Moskova'ya davet edilmiş ve Saraçoğlu 25 Eylül 1939'da Moskova'ya gitmiştir. Türk heyetinin öncelikli hedefi Sovyetlerle karşılıklı bir yardım ve işbirliği anlaşmasının imzalanmasını sağlamaktır. Diğer yandan Türkiye, İngiltere ve Fransa arasında oluşturulan ittifak ile Türk-Sovyet dostluğu arasında bağlantı noktası arar iken Rusya'nın amacı Montreux'u kendi çıkarlarına göre değiştirmek olmuştur. ${ }^{33}$

Amerikan basını savaş arifesinde Türk-Sovyet yakınlaşmasını ilgiyle takip etmiş ve Türkiye'yi büyük güçler arasında köprü kuracak en önemli devlet olarak görmüştür. Örneğin, Beyaz Saray'in sözcüsü konumundaki The Evening Star gazetesi, Türk-Sovyet görüşmeleri ile Sovyetlerin Müttefiklere katılacağı yönünde değerlendirmeler yapmıştır. Gazete, Moskova'ya gidecek olan Dışişleri Bakanı Şükrü Saraçoğlu tarafından imzalanacak anlaşma ile Türkiye'nin

\footnotetext{
${ }^{26}$ Figen Atabey, “Monterux Konferansı'ndan İkinci Dünya Harbi’ne Türk-Sovyet İlişkileri”, Avrasya Uluslararası Araştırmalar Dergisi, Cilt:2, S.4, Ocak 2014, s. 3-4.

${ }^{27}$ Agm, s.3-4.

${ }^{28}$ Kudret Özersoy, "Montreux Boğazlar Sözleşmesi”, Türk Dış Politikası, Ed. Baskın Oran, İletişim Yayınları, İstanbul, 2009, s. 372.

${ }^{29}$ Age., s. 373.

${ }^{30}$ Tellal, age., s. 321.

${ }^{31}$ Annette B. Fox, The Power of Small States Diplomacy in World War II, The University of Chicago Pres, Chicago, 1959, s. 12.

${ }^{32}$ Soysal, age., s. 275.

33 Barış Ertem, "Türkiye Üzerindeki Sovyet Talepleri ve Türk-Sovyet İlişkileri (1939-1947), Uluslararası Sosyal Araştırmalar Dergisi, Vol. 3, 11, Bahar, 2010, s. 253.
} 
Çanakkale Boğazı'ndaki konumunu güçlendireceğini öne sürmüştür. Ayrıca, Balkanların "dostça olmayan bir güç" tarafindan işgalinin önleneceği ön görüsünde bulunmuştur. ${ }^{34}$

Görüşmelerde, Sovyet Dışişleri Bakanı Molotov, Karadeniz'e kıyısı olmayan devletlerin savaş gemilerinin Boğazlardan geçişi için Türk ve Sovyet Hükümetlerinin birbirine danışması, Karadeniz'e kıyısı olmayan devletlere tonaj kısıtlaması getirilmesi ve karşılıklı mutabakat sağlanmadan sözleşmede değişiklik yapılmaması konularında isteklerde bulunmuştur. ${ }^{35}$ Molotov'un talepleri sonrası Amerikan basınındaki iyi hava yerini endişeye bırakmıştır. The Evening Star gazetesinden -savaş dönemlerinin etkin muhabiri- Dewitt Mackenzie, Sovyetlerin, Çanakkale Boğazı'nı çıkarlarına karşı olan gemilere kapatmak için bir anlaşma sağlamaya çalıştığını iddia etmiştir. ${ }^{36}$ Yine aynı gazetede, Ortadoğu ve Türkiye ile ilgili değerlendirmeleriyle tanınan Constantine Brown, eski Çarın İstanbul'a Rus bayrağını dikme hayalinin gerçekleşebileceğini söylemiştir. ${ }^{37}$

Moskova'da Türk yetkililer ile Sovyet yetkililer arasında, 1 Ekim, 13 Ekim ve 15 Ekim'de birer toplantı daha gerçekleştirilmiş ve Montreux Antlaşması'nın değiştirilmesi tekrar gündeme getirilmiştir. Bu görüşmelerde, Boğazların iki devlet tarafından ortak savunulması, Karadeniz'e sahili olmayan devletlerin Boğazlardan geçemeyeceği garantisinin anlaşmaya eklenmesi, İngiltere ve Fransa ile yapılan müzakerelerin istişareye çevrilmesi, İngiltere ile Fransa'nın Sovyetler ile savaşa girmesi durumunda üçlü ittifakın geçersiz sayılması gibi dayatmalarla karşı karşıya kalan Türk Heyeti, 20 Ekim 1939'da Türkiye'ye dönmüştür. ${ }^{38}$

Saraçoğlu'nun Türkiye'ye döndüğü gün Başbakan Refik Saydam'ın ikili görüşmelere yönelik açıklamaları Demokrat çizgide yayın yapan The Key West Citizen gazetesinde yayınlanmıştır. Haberde, Saydam'ın Rusya taleplerinin, Türkiye'nin Boğazlar politikasına aykırı olduğu gerekçesiyle reddedildiğini duyurmuştur. Başbakan, Rus tekliflerinin Türkiye güvenliğine aykırı olduğunu ve Türkiye'nin İngiltere ve Fransa'ya olan önceki taahhütleriyle bağdaşmadığını söylemiştir. ${ }^{39}$

Türkiye, Sovyetlerle umduğu anlaşmayı imzalayamayınca 19 Ekim 1939 tarihinde İngiltere ve Fransa ile Üçlü Paktı ${ }^{40}$ imzalamıştır. ${ }^{41}$ The Key West Citizen, anlaşmanın zaten hazır olduğunu ve Rus-Türk konferansının çıkmaza girmesini beklediğini aktarmıştır. ${ }^{42}$ The Evening Star gazetesi de görüşmeler devam ederken Üçlü Pakt için askeri hazırlıkların önceden yapıldığını aktarmıştır. ${ }^{43}$ Aynı gazetenin yazarlarından Dewitt Mackenzie, Türklerin, Moskova'nın gücüne karşı koyarak Akdeniz ile Karadeniz'i bağlayan Boğazların "bekçisi" olduğunu ispatladığını belirtmiştir. Mackenzie, Mustafa Kemal Atatürk'ün, herkesle dostluk ve ittifaklar politikasının artık geçerli olmadı̆̆ını, Türklerin kendilerini yeniden konumlandırdıklarını iddia etmişstir.

\footnotetext{
34، Türkler, Sovyet ile Yapılacak Anlaşmanın Rusya'yı Müttefiklere Katılmaya Götürebileceğini Öngörüyor” The Evening Star, 22 Eylül 1939, s.1.

${ }^{35}$ Kamuran Gürün, Türk-Sovyet İlişkileri (1920-1953), Türk Tarih Kurumu Yayınları, Ankara, 2010, s. 204-205.

${ }^{36}$ Dewitt Mackenzie "Avrupa'da Savaş” The Evening Star, 26 Eylül 1939, s. 7.

${ }^{37}$ Constantine Brown, "Değişen Dünya", The Evening Star, 27 Eylül 1939, s. 3.

${ }^{38}$ Ertem, agm., s. 254-255.

39 “Türkiye Yeni Rus Tekliflerini Reddetti”, The Key West Citizen, 18 Ekim 1939, s. 4.

${ }^{40}$ Üçlü Pakt, Türkiye'ye karşı bir Avrupa devletinin (Almanya) saldırısı durumunda İngiltere ve Fransa'nın yardım etmesi ile birlikte Akdeniz ülkesinin (İtalya) saldırısında yine iki ülke tarafından karşılıklı yardım yapılması temeline dayandırılan antlaşmadır. Ayrıntılı bilgi için Bkz.: Soysal, age., s. 599-618.

${ }^{41}$ Feridun C. Erkin, Türk Sovyet İlişkileri ve Boğazlar Meselesi, Başnur Matbaası, Ankara, 1968, s. 156-157.

${ }^{42}$ The Key West Citizen, 19 Ekim 1939, s.1.

43 “Türk Misyonu, Ekonomik-Askeri Anlaşmaları Londra'ya Götürdü”, The Evening Star, 1 Ekim 1939, s. 1.
} 
"Zekice bir politika seçimi yaptılarsa, etkilerinin hızla yayılması muhtemeldir, çünkü dünyanın o kısmı lider aramaktadır. Türkiye'nin komşularlyla olan ilişkileri iyi olarak görülüyor. Sadece Balkan taraftarında lider değil - Türkiye, Yugoslavya, Yunanistan ve Romanya - aynı zamanda İran, Irak ve Afganistan'la anlaşma halinde. "44

Constantine Brown ise Üçlü Paktı, totaliterler için kötü, Fransızlar, İngilizler ve bazı Amerikan silah üreticileri için iyi olduğunu söylemiş, Sovyetlerin Türkiye'ye karşı derhal saldırmasının mümkün olmadığını, ancak Türklerin hazır olması gerektiğine de dikkat çekmiş̧irir. $^{45}$

Üçlü Pakt sonrası Sovyetler, Türkiye'nin yanlış tarafı seçtiği yönünde propaganda faaliyeti yürütmüş, bu taktik Türk-Sovyet ilişkilerini gerginleştirmiştir. İngiltere basınında iki ülke arasındaki ilişkilerin kötü olduğu ve hatta savaş boyutuna geldiğine dair haberler çıkması dikkat çekicidir. ${ }^{46}$ Sovyet Rusya hükümet gazetesi Izvestia, Rusya’nın, Türkiye'nin yeni ittifakı nedeniyle bir pişmanlık duymadığını, isterse Çanakkale'yi işgal etmekte özgür olduğu ve Üçlü Paktın "Türkiye'yi savaşın yörüngesine sürüklediğini" duyurmuştur. ${ }^{47}$

Rus basınında tehdit içeren bu gelişmeler sonrası Amerika ve İngiltere'nin olası bir savaş durumu için Türkiye'yi hazırlamaya çalıştığını söylemek mümkündür. Örneğin, The Evening Star gazetesinde David Lloyd George, Türkiye'nin, bir milyonluk büyük bir ordusu olduğu gibi ekonomik anlamda büyük çaplı bir savaşı yürütebilecek durumda olduğunu iddia etmiştir. ${ }^{48}$ Ayrıca, bir zamanlar “Avrupa'nın hasta adamı”nın bugün Avrupa'nın anahtar ülkesi olduğunu aktarmıştır. $^{49}$ Cumhuriyetçi kanada yakın The Midland Journal gazetesi ise Türkiye'nin, Avrupa gücünün dengesini sağlayacağını belirtmiştir. ${ }^{50}$

Türk-Sovyet görüşmeleri istenilen şekilde sonuç vermese de, iki ülke arasında düşmanca bir tavır oluşmamış hatta 1941 yılının ilk yarısında Alman ve İtalyanların, Avrupa'daki revizyonist politikalar sonucu Yunanistan ve Bulgaristan'1 işgal etmesi, Sovyetlerin Türkiye'ye yakınlaşmasına sebep olmuştur. ${ }^{51} \mathrm{Bu}$ bağlamda, 25 Mart 1941 tarihinde Sovyetler tarafindan bir deklarasyon yayınlanarak, İngiliz medyasında yer alan Türk-Sovyet savaşı çıkacağı yönündeki haberlerin doğru olmadığını, Türkiye'nin saldırıya uğraması veya savaşa girmesi durumunda Sovyetlerin 1925 Saldırmazlık Paktı kapsamında tarafsızlığına güvenebileceğini iletmiş, Türkiye de aynı yönde karşılık vermiştir. ${ }^{52}$ Ağustos ayında İngiltere ve Sovyetler ortak bir notayla Boğazlar statüsünün korunacağını bildirmişlerdir. ${ }^{53}$

Türkiye'nin Üçlü Paktı imzalamasından sonra Amerika'nın, Türkiye'yi Sovyetlere karşı durabilecek, bölgesinin önemli bir gücü olarak gördüğünü söylemek mümkündür. Bu süreçte Amerikan basınında, Türkiye'ye yönelik bir sempati havası estiği ve Sovyetlerin sürekli savaş isteyen taraf olduğuna yönelik adeta bir kampanya başlatıldığı görülmektedir.

\footnotetext{
${ }^{44}$ Dewitt Mackenzie, “Türkler Müttefiklerle Anlaşma İmzaladı”, The Evening Star, 19 Ekim 1939, s. 2.

${ }^{45}$ Constantine Brown, "Türk Paktı, Müttefikler ve ABD Silah Üreticileri İçin İyi Bir Haber Ancak Diktatörler İçin Kötü” The Evening Star, 20 Ekim 1939, s. 2.

${ }^{46}$ Erkin, age., s. 160.

47 "Rusya, Türkiye'yi Uyaryor", The Evening Star, 22 Ekim 1939, s. 4.

${ }^{48}$ David Lloyd George, "Türkiye Belirleyici Faktör", The Evening Star, 22 Ekim 1939, s. 3.

49 "Türkiye Neden Önemli?", The Evening Star, 27 Ekim 1939, s. 6.

50 Joseph W. Labine, "Müttefikler, Nazi Havasına Türk Diplomatik Darbesiyle Karşı Koyabilir", The Midland

Journal, 27 Ekim 1939, s. 2.

${ }^{51}$ Uçarol, age., s. 900.

52 William Hale, Türk Dış Politikası 1774-2000, Mozaik Yayınları, İstanbul, 2003, s. 82.

${ }^{53}$ Aydin, age., s. 447,
} 


\section{1925 Antlaşması'nın İptali ve Sovyet Taleplerinin Amerikan Basınına Yansıması}

1942 sonundan itibaren özellikle Stalingrad'da Sovyetlerin Almanlar karşısında üstünlük sağlaması, Türkiye ile politikasında değişimlere neden olmuş, Müttefikler, nihai başarı için Türkiye'nin savaşa girmesini zorunlu görmüşlerdir. İlk teşebbüs 30-31 Ocak 1943 tarihinde Adana'da İnönü ve Churchill arasında gerçekleşen görüşmedir. Müttefikler, Almanların artık Türkiye için tehlike oluşturmayacağı, Almanların petrol merkezlerine girişilecek bir saldırı karşısında Türkiye'nin silahlandırılmasının gerektiği, bu kapsamda 1943 yılı bitmeden savaşa girmesi talep edilmiştir. ${ }^{54}$

19 Ekim 1943 tarihinde Moskova'da toplanan Müttefikler Dış İlişkiler Bakanlığı Konferansı'nda ise Türk hava üslerinin Müttefik kullanımına açılması kararlaştırılmıştır. ${ }^{55} \mathrm{Bu}$ konu Kahire Konferansı'nda tartışılmış, Türkiye, prensipte Almanlara karşı savaşa girebileceğini ancak yeterli donanımın sağlanmasını istemiş, üs kullanımına ise izin vermeyeceğini belirtmiştir. ${ }^{56}$ Müttefikler aynı taleplerini 4-6 Aralık tarihinde İkinci Kahire Konferansı'nda Cumhurbaşkanı İsmet İnönü'ye bildirmişler, İnönü gerekli askeri destek sağlanması durumunda savaşa girilebileceğini söylemiş ancak herhangi bir tarih vermemiştir. ${ }^{57}$ Kahire görüşmelerinden sonra dikkat çeken husus Türkiye'nin savaşa girmeyeceğine ikna olan Sovyetlerin, Almanları, Türkiye'nin sağlayacağı avantajlar olmadan yenebileceği hissine kapılması ve artık Türkiye'nin savaşa katılmasını istememesidir. ${ }^{58} \mathrm{Bu}$ gelişmelerden sonra Türkiye, 2 Ağustos tarihinde Almanya, 3 Ocak 1945 tarihinde Japonya ile tüm ilişkisini kesmiş olsa da Sovyet görüşünde bir değişiklik olmamıştır. ${ }^{59}$

1945 yılı savaşın sonunun geldiği yıl olmuş, yenidünya düzeninin tartışmaları 1şı̆̆ı̆ında Roosevelt, Stalin ve Churchill 4-11 Şubat 1945 tarihinde Yalta'da buluşmuşlardır. ${ }^{60}$ Görüşmelerde Stalin, Boğazların Türkiye tarafından kapatılmasından rahatsızlık duyduğunu belirtmiş, Roosevelt ve Churchill'in de hak vermesiyle Türkiye'nin egemenlik haklarını engellemeyecek şekilde Boğazlarda (Montreux Sözleşmesi'nde) yeni düzenleme yapılmasına karar verilmiştir. ${ }^{61}$ The Evening Star gazetesinde Dorothy Thompson, Yalta Konferansı'ndan çıkan tek sonucun Rusya'nın Akdeniz'e erişip erişemeyeceği ve sonunda Boğazlara hükmedip etmeyeceğinden ibaret olduğu iddiasında bulunmuştur. ${ }^{62}$

Yalta Konferansı'nda, Birleşmiş Milletlerin kurulmasına sebep olacak San Fransisco Konferansı'na, Almanya ve Japonya'ya savaş ilan etmiş ülkelerin katılabileceğinin kararlaştırılması üzerine ${ }^{63}$ Türkiye 23 Şubat tarihinde Almanya ve Japonya'ya savaş ilan etmiştir. ${ }^{64}$ The New York Times, oylama öncesi yapılan meclis tartışmasında, dostane Türk-Rus

\footnotetext{
${ }^{54}$ Geoffrey Roberts, "Moscow's Cold War on the Periphery: Soviet Policy in Greece, Iran, and Turkey, 1943-8" Journal of Contemporary History, Vol. 46, No. 1, 2011, January, s. 58-81.

${ }^{55}$ The Foreign Relations of the United States (FRUS), The Conferences at Cairo and Tahran 1943, Pre-Conference Papers, 1 November 1943, s. 135.

${ }^{56}$ Erkin, age., s. 216.

57 Yuluğ Tekin Kurat, "Kahire Konferansı Tutanakları (4-7 Aralık 1943) ve Türkiye'yi Savaşa Sokma Girişimleri”" Belleten, C.XLVII, 1983, S.185, 298-335, s. 330.

${ }^{58}$ Gürün, age., s. 262.

${ }^{59}$ Uçarol, age., s. 922.

${ }^{60}$ Aydin, age., s. 472.

${ }^{61}$ FRUS, The Conferences at Malta and Yalta, III, The Yalta Conference, 1945, 11 February 1945, s. 982.

${ }^{62}$ Dorothy Thompson, “Kayıtta!”, The Evening Star, 23 Şubat 1945, s. 6.

${ }^{63}$ FRUS, The Conferences at Malta and Yalta, III, The Yalta Conference, 1945, 11 February 1945, s. 976.

${ }^{64}$ Erkin, age., s. 245.
} 
ilişkileri ve Müttefik dostluğunun vurgulandığını duyurmuştur. Şemsettin Günaltay’ın, kurtuluş mücadelesinde Rusların sadık bir dost olduğunu söylediği aktarılmıştır. ${ }^{65}$

Türkiye'nin savaş ilanlarını değerlendiren bağımsız The Wilmington Morning Star gazetesi San Fransisco Konferansı'na Türklerin hayati bir ilgisi olduğunu çünkü Boğazların Türk olduğunu görmek ve Türkiye kıyılarının savunulması için gerekli olduğuna inandıklarını ve bazı Ege Adaları'na sahip olmayı arzuladıklarını açıklamıştır. ${ }^{66}$ Constantine Brown ise barış konferansının Türklere toprak kazandırmayacağını, Türklerin tek amacının Boğazların kontrolü konusundaki büyük endişesini gidermek olduğunu belirtmiştir. ${ }^{67}$

Yalta Konferansı'nda da Boğazlar konusu gündeme gelince Büyükelçi Selim Sarper, Montreux Sözleşmesi ile ilgili Sovyet isteklerini öğrenmek için Dışişleri Bakanı Molotov'u ziyaret etmiştir. ${ }^{68} 19$ Mart tarihinde gerçekleşen görüşmede Molotov, 17 Aralık 1925 tarihinde imzalanan Türk-Sovyet Saldırmazlık Antlaşması'nın yürürlük süresinin sonuna gelindiğini, savaş esnasında yaşanan gelişmeler nedeniyle Antlaşmanın günün şartlarına uymadığını, düzenlemeye ihtiyaç duyduğunu belirtmiş ve Sovyet Hükümeti'nin, Antlaşmayı feshetmek istediğini bildiren notayı sunmuştur. ${ }^{69}$

Amerikan basınının da bu gelişmeyi sadece Montreux Antlaşması'nda değişiklik için bir adım olarak gören yayınlar olduğu gibi Rusların genişlemeci politikalar güttüğünü savunan yayınlar da olmuştur. Örneğin, The Wilmington Morning Star gazetesi gelişme ile ilgili şaşkınlığını belirterek kararın Türkiye'yi Rus yörüngesine sokmayı hedeflediğini, Sovyetlerin genişleyen gücüne paralel olarak daha fazla pozitif taahhüt içeren bir anlaşma yapmak istediğini belirtmiştir. ${ }^{70}$ The Evening Star gazetesi ise Pakt iptalini Montreux anlaşmasının gözden geçirilmesi için hazırlık aşaması olarak değerlendirmiştir. ${ }^{71}$

Sovyet notasını Amerikan politikası açısından değerlendiren Constantine Brown ise Amerikan Hükümetinin, Rusya'nın Boğazlar ile ilgili tarihsel hedeflerine karşı olmadığını belirtmiştir. $^{72}$ The Wilmington Morning Star gazetesi, Sovyet kararının Washington'da herhangi bir sürpriz veya hayal kırıklığına sebep vermediğini ancak, zamanı geldiğinde Rusların, Türklerin aşırı olarak değerlendireceği şeyleri isteyebileceğinden hareketle Washington'un rahatsız olduğunu belirtmiştir. ${ }^{73}$

Türkiye söz konusu notaya 4 Nisan tarihinde cevap vermiştir. Notada, iki ülke arasındaki günün menfaatlerine uygun bir anlaşmanın yapılabileceği bu kapsamda Sovyetlerin tekliflerini değerlendirebileceği iletilmiştir. ${ }^{74}$ The Wilmington Morning Star, Türkiye'nin, "gerçek çıkarları daha iyi teyit etmeyi" sağlayan yeni bir anlaşma önerisi yaptığını, Türk cevabının iki ülke arasındaki samimi dostluğu sürdürme ve pekiştirme isteğini dile getirdiğini aktarmıştır. ${ }^{75}$ The New York Times ise Türkiye ve Sovyetler arasındaki görüşmelerin Sovyetlerin başkanlığında

\footnotetext{
${ }^{65}$ Joseph M. Levy, “Türkiye, San Fransisco Konferansında Koltuğunu Almak İçin Savaş İlan Etti”, The New York Times, 24 Şubat 1945, s. 1.

66 “Türkiye, Almanya ve Japonya'ya BM İçin Savaş İlan Etti”, The Wilmington Morning Star, 24 Şubat 1945, s.1.

${ }^{67}$ Constantine Brown, "Değişen Dünya”, The Evening Star, 28 Şubat 1945, s. 10.

${ }^{68}$ Erkin, age., s. 276.

${ }^{69}$ Metin Toker, Türkiye Üzerinde 1945 Kâbusu, Akis Yayınları, Ankara, 1971, s. 5.

70 “Kızıllar, Türk Anlaşmasının Geçersiz Olduğunu Açıkladı”, The Wilmington Morning Star, 22 Mart 1945, s. 5.

71 “Türklerin Öngördüğü İyileştirilmiş Sovyet Anlaşması”, The Evening Star, 22 Mart 1945, s. 3.

${ }^{72}$ Constantine Brown, "Değişen Dünya", The Evening Star, 23 Mart 1945, s. 6.

73 "Rus Siyaseti: Türkiye", The Wilmington Morning Star, 6 Nisan 1945, s. 4.

${ }_{75}^{74}$ Aydin, age., s. 473.

75 “Türkiye, Antlaşmanın Feshi Konusunda Kızıllarla Hemfikir; Yeni Dostluk Antlaşması Öneriyor", The Wilmington Morning Star, 9 Nisan 1945, s.1.
} 
boğazlarda uluslararası bir komisyon tarafından kontrolü ve Boğazlardan herhangi bir ülkeye savaş durumunda müdahale için üs talebinde bulunması ekseninde olacağını duyurmuştur. ${ }^{76}$

Türk notasına 7 Haziran tarihinde verilen Sovyet cevabında anlaşma yapılmadan önce 1921 Moskova Antlaşması ile Türkiye'ye bırakılan Ardahan ve Kars illerinin Sovyetlere terki, ${ }^{77}$ Boğazların birlikte savunulması, Sovyetlere deniz ve kara üsleri tahsisi ile Montreux konusunda ortak karar verilmesi yönünde mutabakata varılması talep edilmiştir. ${ }^{78}$ Türkiye, $^{2}$ arazi terki ve Boğazlarda üs verilmesi konularının müzakere dahi edilmeyeceğini, Montreux Sözleşmesi'nin uluslararası nitelik taşıması nedeniyle iki ülke arasında tartışılamayacağını belirtmiş, ancak 18 Haziran'daki ikinci görüşmede Molotov, Sovyetlerin taleplerinde 1srarc1 olduğunu söylemiştir. $\mathrm{Bu}$ gelişme üzerine Türkiye bir İttifak anlaşması fikrinden vazgeçmiştir. $^{79}$

Sovyetlerin son notasıyla taleplerinde ısrarcı oluşu, Amerikan basınında konunun ayrıntılı tartışılmasına neden olmuştur. Basının genel değerlendirmesi doğal suyolu olan Boğazlar rejimini düzenleyen Montreux Antlaşması'nın tekrar gözden geçirilebileceği yönünde olurken, Sovyetlerin toprak taleplerinin hukuki olmadığ 1 hatta Türkiye'ye BM nezdinde başvuru yapma hakkı doğurduğu iddia edilmiştir. Amerikan basınının doğal suyolları özelinde ayrım yapmasının temelinde, Panama Kanalı gibi insan yapımı kanallar ile ilgili olası Sovyet taleplerini engellemeye yönelik bir manevra olduğunu söylemek mümkündür.

The Key West Citizen gazetesi, ikili görüşmelerdeki olumsuz havaya rağmen Boğazlar ile ilgili görüşmelerin başlayacağını çünkü Rusya'nın, Boğazlar konusunda Türkiye'ye bağımlı olduğunu belirtmiştir. ${ }^{80}$ Constantine Brown, Sarper ile Molotov arasındaki görüşmeleri "zor ve nahoş" olarak tanımlamıştır. Brown, Sovyetlerin güvenlik ve emniyeti için Boğazlar bölgesinin tamamı üzerinde tam kontrol sahibi olmak istediğini hatta talepleri içinde İstanbul'un da olduğunu belirtmiştir. ${ }^{81}$

The Evening Star, manşetine “Türkiye, Çanakkale Boğazı'nın Değişmesini İsteyen Kızıl Raporundan Rahatsız” başlığını atmış, Türkiye'nin duyduğu rahatsızlığı ABD ve İngiltere'ye bildirdiğini aktarmıştır. Gazete, Montreux Sözleşmesinin uluslararası olarak müzakere edilebileceğini ve Büyük Güçlerin çok taraflı bir anlaşması ile değiştirilebileceğini aktardıktan sonra Kars talebinin San Francisco Tüzügü’nün Türkiye'ye protesto için net bir zemin vereceğini belirtmiştir. ${ }^{82}$

San Fransisco Konferansı, 25 Nisan tarihinde toplanmıştır. Konferans sırasında Dışişleri Bakanı Hasan Saka ile Molotov arasında Türk notası hakkında bir takım görüşmeler gerçekleşmiş ancak Molotov cevap vermemeyi tercih etmiştir. ${ }^{83}$ The Wilmington Morning Star gazetesi ise Saka ile İngiliz Dışişleri Bakanı Anthony Eden'in Konferans sırasında konu hakkında görüştüğünü ve Eden'in, Rusya'nın, Montreux anlaşmasını gözden geçirme talebini desteklediğini bildirmiştir. ${ }^{84}$

\footnotetext{
${ }^{76}$ Clifton Daniel, “İngiltere, Rusya Hakkındaki Görüşlerini Pekiştiriyor”, The New York Times, 11 Mayıs 1945, s. 4.

${ }^{77}$ Roberts, agm., s. 74.

${ }^{78}$ Erkin, age., s. 253.

${ }^{79}$ Gürün, age., s. 286-288.

80 "Rusya-Türkiye Görüşmesi Planlandı", The Key West Citizen, 26 Haziran 1945, s.1.

${ }^{81}$ Constantine Brown, "Değişen Dünya", The Evening Star, 22 Haziran 1945, s. 6.

82 “Türkiye, Çanakkale Boğazı'nın Değişmesini İsteyen Kızıl Raporundan Rahatsız”, The Evening Star, 27 Haziran 1945 , s. 2.

${ }^{83}$ Gürün, age., s. 279.

${ }^{84}$ The Wilmington Morning Star, 12 Temmuz 1945, s.3.
} 
San Fransisco Konferansı'nda somut adımlar atılamayınca konunun artık Potsdam Konferansı'nda tartışılacağı anlaşılmıştır. Constantine Brown, Potsdam Konferansı'nda gündemin en önemli konusunun Türk meselesi olacağını ve İngiltere'nin, Türkiye'nin parçalanmasına karşı ilgisiz kalamayacağını belirtmiştir. Brown, Boğazlar konusunda Amerikan bakış açısının mantıklı ve basit olduğunu, Panama, Süveyş ve Kiel Kanalları gibi insan dehalarının yarattığı suyollarının ilgili ülkeler tarafından kontrol edilmesi gerektiğini, Çanakkale Boğazı gibi doğal suyollarının ise hiç kimsenin kontrolü altında olmaması ve her zaman tüm ülkelere özgür ve açık olması gerektiğini açıklamıştır. Brown, Rusya ile Türkiye arasındaki ikinci çekişmenin, stratejik Ardahan ve Kars illerinin iade edilmesine yönelik talebin olduğunu ve Moskova'nın Türklerin böyle bir imtiyazı kabul etmesi halinde, Türkiye'nin Suriye Halep vilayeti ile tazmin edileceğini belirttiğini iddia etmiştir. ${ }^{85}$ Demokrat The Key West Citizen de Sovyetlerin, Boğazlar ile ilgili olarak teminatlar istemesinin "tamamen" doğal olduğunu belirtmiştir. ${ }^{86}$

Potsdam Konferansı 17 Temmuz tarihinde başlamış, Sovyetler, tüm taleplerini tekrarlamıştır. ${ }^{87}$ Stalin, Marmara'da bir pozisyon elde edemeyeceklerse, Yunanistan'dan (Dedeağaç) bir askeri üssün kendilerine verilmesini istemiştir. ${ }^{88}$ Görüşmeler esnasında yeni Amerikan Başkanı Truman üç büyük devletin kontrolünde bir çözüm önermiştir. ${ }^{89}$ Görüşmelerin sonucunda Montreux Sözleşmesi'nin günün şartlarına uymaması sebebiyle değişmesi ve ayrıca Türk Hükümetiyle ayrı ayrı tartışılarak sonuçlandırılması kararlaştırılmıştır. ${ }^{90}$

Potsdam Konferansı'nda alınan kararlar sonrası Montreux Antlaşması'nın değişeceğine yönelik hava, 9 Ağustos tarihinde Başkan Truman'ın doğal tüm suyollarının uluslararasılaştırılmasına ${ }^{91}$ yönelik açıklaması ile sarsıntıya uğramıştır. Çünkü, Sovyetlerin asıl planı Montreux Antlaşması'nda düzenlenen geçiş rejimine yönelik Karadeniz devletlerine inisiyatifler sunması ve Boğazların askeri kontrol ve savunmasında Rusya'nın mutlak söz sahibi olmasına yönelik amaçlar içermektedir. Truman'ın açıklamaları Sovyetleri memnun etmemiştir. The Evening Star gazetesinde röportajı yayınlanan Başkan Truman, Rusya'nın ana hedefi olan Boğazlar'da "bencil kontrol” yerine Avrupa'nın diğer iç suyollarında olduğu gibi "serbest ve sınırsız geçiş" önermiş, bu önerinin Dışişleri Bakanları Konseyine iletildiğini ve "orada ABD'nin kabul edilmesi için baskı yapmayı planladı̆̆ını" söylemiştir. ${ }^{92}$ Başkan Truman'ın açıklaması Sovyetlerce tepkiyle karşılanmıştır. ${ }^{93}$

Başkan Truman'ın Sovyetleri zor durumda bırakan manevrasına rağmen Potsdam kararları gereğince ABD, İngiltere ve Rusya Dışişleri Bakanları 11 Eylül 1945 tarihinde Londra'da toplanmıştır. ${ }^{94}$ Amerikan basını Konferansta Sovyetlerin, Türkiye'ye ait Boğaz güvenliğinin arttırılmasını ve Boğazların kontrolünün Rusya, Romanya, Bulgaristan ve Türkiye'den oluşacak uluslararası bir heyet tarafından yapılmasını önerdiğini açıklamıştır. ${ }^{95}$ The Wilmington

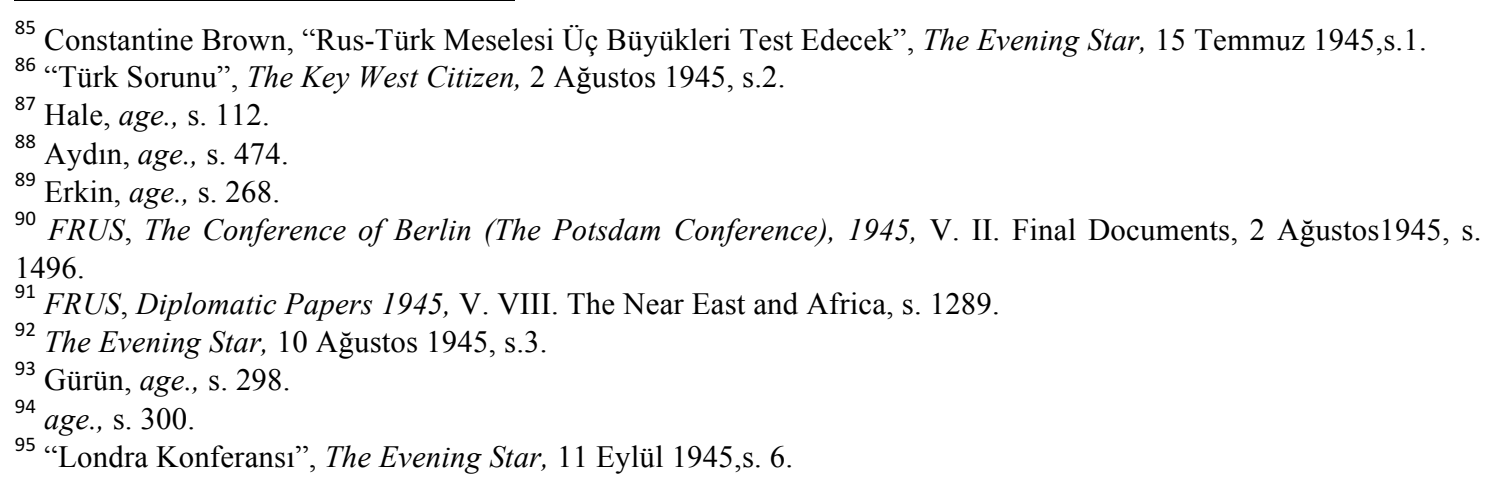


Morning Star gazetesi Türkiye'nin, Boğaz kontrolünü Rusya'ya devretmek yerine büyük güçlerin kontrolünü tercih edeceğini açıklamıştır. ${ }^{96}$

Constantine Brown, Başkan Truman'ın Boğazlar ile ilgili bütün ulusların savaş gemilerine ve ticaret gemilerine sınırsızca açık olması teklifinin Türkler tarafından kabul edildiğini ancak Molotov'un kabul etmediğini açıklamıştır. Molotov'un, yalnızca Marmara Denizi'ne girişi değil, aynı zamanda Karadeniz'e girişi de zorla kontrol etmeye kararlı olduğu, Türkiye'nin ise Rusya'nın taleplerinin özel bir konferansta veya BM toplantısında görüsşmek istediğini aktarmıştır. Brown, sözlerine savaş ihtimalinin varlığından bahsederek sonlandırmıştır. "Ruslar kendilerine ait olduğuna inandıkların almaya karar verirse, Türkler ezici ihtimaller olsa bile savaşacaklar." 97 Brown, 27 Ekim tarihli yazısında ise Başkan Truman'ın, Türk-Sovyet münasebetleri nedeniyle endişeli olduğunu ancak her iki milletin de BM üyesi olması sebebiyle birbirlerine karşı savaşamayacaklarını taahhüt ettiğini belirtmiş, İngiltere'nin ise bazı "olayların" şiddet içeren eylemleri hızlandırmak için bir bahane olarak kullanılabileceğinden korktuğunu aktarmıştır. ${ }^{98}$ The New York Times gazetesinde C.L.Sulzberger'in Amerika ve İngiltere'nin tutumlarını değerlendirdiği makalesinde, Anglo-Amerikan görüşmelerinin en önemli gündem maddesinin Sovyetlerin karşısına Anglo-Amerikan duruşu oluşturmak olduğunu iddia etmiştir. ${ }^{99}$

Sovyetlerin ısrarcı ve savaş ihtimali taşıyan sert tutumu Türkiye'ye geri adım attırmamış aksine TBMM'nin açılışında Cumhurbaşkanı İsmet İnönü adeta Sovyet taleplerine meydan okumuştur. "Türk topraklarından ve haklarından hiç kimseye verilecek bir borcumuz yoktur. Şerefli insanlar olarak yaşayacă̆ız ve şerefli insanlar olarak öleceğiz." 100

Potsdam kararları gereği Amerika, Boğazlar ile ilgili notasını 2 Kasım tarihinde Türk Dışişlerine bildirmiştir. ${ }^{101}$ Amerika, Boğazların ticaret gemilerine ve Karadeniz güçlerinin savaş gemilerinin transit geçişine her zaman açık olmasını, Karadeniz'de sahili olmayan devletlerin savaş gemilerine ise BM otoritesi dışında kapalı olmasını, Japonya'nın Antlaşmadan çıkarılmasını ve Montreux Antlaşması'nda günün şartlarına yönelik değişiklikler yapılmasını teklif etmiştir. ${ }^{102}$ The New York Times gazetesinde ABD Dışişleri Bakanı Byrnes'ın açıklamasına yer verilerek Amerika'nın, Sovyetlerin Boğazlardan geçişine hak verdiğini ancak askeri anlam taşıyan üs talebine karşı olduğunu açıklamıştır. ${ }^{103}$ Amerikan notasını, Montreux Antlaşması kapsamında yapılacak bir değişikliğe yönelik konferans toplanmasını onaylayan İngiliz notası izlemiştir. ${ }^{104}$ Amerikan ve İngiliz tutumu incelendiğinde, Türkiye'nin, savaşan ülkelerin savaş gemilerine veya kendini tehdit ettiğini düşündüğü tüm savaş gemilerine olan sınırlarını kapatan yetkinin elinden alındığı göze çarpmaktadır.

Sovyetler, Amerikan notasını alır almaz Büyük Elçi Vinogradov aracılığıyla Karadeniz devleti olmayan savaş gemilerinin geçişinin nasıl engelleneceğine yönelik endişesini dile getirmiş, Türkiye'nin bu görevi üsleneceği kendisine belirtilince Türkiye'nin bunu

\footnotetext{
96 “Beş Büyükler, İtalya'yı Sömürgelere Dağıtabilir”, The Wilmington Morning Star, 16 Eylül 1945, s.1.

${ }^{97}$ Constantine Brown, "Değișen Dünya", The Evening Star, 15 Ekim 1945,s. 8.

98 Constantine Brown, "Değişen Dünya", The Evening Star, 27 Ekim 1945, s. 8.

${ }^{99}$ C.L.Sulzberger, "Müttefikler, Boğazlar Meselesine Çalışıyor", The New York Times, 30 Ekim 1945,s. 4.

${ }^{100}$ TBMM, Zabit Ceridesi, 7. Dönem, 4. Yasama Y11, Cilt 201. (1.11.1945).

${ }^{101}$ Gürün, age., s. 300.

102 FRUS, Diplomatic Papers 1945, V. VIII. The Near East and Africa, s. 1265.

103 “Amerika'nın Türkiye'ye Notası”, The New York Times, 1 Kasım 1945, s. 9.

104 “Boğazlar ile ilgili İngiliz Notası Türk Kabinesine Verildi”, The New York Times, 26 Kasım 1945, s. 3.
}

\section{History Studies}


yapamayacak kadar zayıf olduğunu ve bir savaş sırasında Sovyet güvenliğinin kendileri tarafından Türk topraklarından verilecek üsler ile sağlanacağını açıklamışlardır. ${ }^{105}$

The Evening Star gazetesinde Garnett D. Horner, Amerika'nın nota ile Çanakkale boğazının kullanımına yönelik kısıtlamaları kaldırmayı planladığını ${ }^{106}$ ancak Sovyetlere hiç bir üs verilmeyerek Türklerin toprak bütünlüğ̈̈nü korunduğu belirtilmiştir. ${ }^{107}$

Sovyetler, Amerikan notası sonrası propaganda faaliyetlerini hızlandırmıştır. Tiflis gazetesinde iki Gürcü profesörün tüm Karadeniz sahilinin Gürcistan toprağı olduğuna yönelik istekleri Rus Harvestia, Red Star ve Pravda gazetelerinde yayınlanmıştır. Mektupta, Artvin, Ardahan, Oltu, Tortum, İspir, Bayburt, Gümüşhane, Giresun ve Trabzon bölgesinin Gürcülere devrinin istendiği açıklanarak mektuptan ifadelere yer verilmiştir.

"Türkiye tarafindan ele geçirilen antik topraklarımızın durumu hakkında dünya vicdanına hitap ediyoruz. Küçük bir bölgesel anlaşmazlıktan bahsetmiyoruz. Bu, halkımızın topraklarını ikiye bölerek ele geçiren bir suçla ilgilidir. Gürcü halkı topraklarını geri almalıdır. "108

The Evening Star gazetesinde Bertram Benedict, Gürcistan taleplerinin, eskiden Ermeni sayılan birçok ilçeyi içerdiğini ve bu taleplerin büyük Çanakkale Boğazı oyununda piyon olarak kabul edilmesi gerektiğini açıklamıştır. ${ }^{109}$

Gürcü talepleri Türk-Sovyet ilişkilerinde Amerika açısından bir dönüm noktası olmuştur. Amerika, Sovyetlerin hemen hemen Türkiye'nin Kuzeydoğu bölgesinin tamamına yakınını, Boğazlar ve üstü kapalı İstanbul talepleri sonrasında ciddi bir savaş tehlikesiyle karşı karşıya kalındığını düşünmüştür. Türkiye ise tehlikenin farkına vararak Amerikan ve İngilizlerin konu hakkındaki düşüncelerini öğrenmek istemiştir. Dışişleri Bakanı Hasan Saka, 10 Ocak 1946 tarihinde Londra'da düzenlenen Birleşmiş Milletlerin ilk Genel Kurulunda, Boğazlar konusunun uluslararası bir konferansta tartışılabileceğini, Türkiye'nin bu konuyu Rusya ile ikili görüşmeler yapmak yerine uluslararası bir temele oturtmayı tercih ettiğini ve Türkiye'nin sınırlarını aşan herhangi bir işgalde savaşa gideceğinin bilinmesi gerektiğini söylemiştir. ${ }^{110}$ Şükrü Saraçoğlu ise Ankara radyosuna yaptığı açıklamada Sovyetler Birliğinin Türk toprağı Kars ve Ardahan'da hiçbir hakkı olmadığını söyleyerek, bu bölgede yaşayan insanların Türk Kültürü, Türk Dini ve Türk Dili ile yaşadıklarını belirtmiştir. Saraçoğlu, Gürcü profesörlerin verdikleri nüfus istatistiklerini şu sözlerle eleştirmiştir.

Gürcü Profesörlerin tarihin dünü veya bugünü hakkında en ufak bir fikirleri yoktur. Yüksek İhtimal Hitler'in "Lebensraum" (Yaşam Alanı) teorisini gerçekleştirmeye çalışıyorlar."111

Türk yetkililerin açıklamaları sonrası Amerikan basınında Türk-Sovyet çekişmesinin karşılıklı görüşmeler ile çözülmesi, her iki tarafın haklarını koruyacak bir çözüm yolunun bulunması ve Boğazlar sorununun sadece Türk-Sovyet değil aynı anda İngiliz-Amerika-Sovyet problemi olduğu değerlendirilmiştir. Örneğin, The Wilmington Morning Star gazetesi öncelikle çözülmesi gereken bir sorun olduğunu kabul etmenin başlı başına iyi bir çözümün temelini oluşturacağını belirtmiştir.

\footnotetext{
${ }^{105}$ Gürün, age., s. 301.

106 Garnett D. Horner, “ABD Sponsorları Çanakkale Boğazı Kullanımına Yönelik Kısıtlamaları Kaldırmayı Planliyor”, The Evening Star, 8 Kasim 1945, s. 4.

107 "Boğazlar Sorunu", The Evening Star, 9 Kasım 1945, s. 8.

${ }^{108}$ Eddy Gilmore, "Rus Basını, Türkiye'nin Karadeniz Kıyısının 180 Milini Talep Ediyor", The Wilmington Morning Star, 21 Aralık 1945, s. 6.

${ }^{109}$ Bertram Benedict "Türkiye Talebi Piyon Gibi, Rusya Sınır Bölgelerine Hâkim Olmaya Kararlı", The Evening Star, 1 Ocak 1946, s. 6.

110 "Rusya, Karadeniz Güçlerinin Kontrolünü İstedi”, The Evening Star, 13 Ocak 1946, s. 1.

111 “Türk Başbakan, Sovyet Teklifini Kınadı”, The New York Times, 7 Ocak 1946, s. 2.
} 
"O zaman Sovyet hükümetine kapının (Boğazlar) kilidini açmak istediğimizi, iki dünya savaşında olduğu gibi ondan bir daha kesilmek istemediğimizi ve bunun ortak bir temele dayandiğın söyleyebiliriz. Ingiltere, Fransa ve ABD'nin, sadece Boğazları değil, Akdeniz'i de açacak olan bir düzenleme (BM güvencesi) yapma yetkisi dâhilindedir. Sovyetler Birliği'nin Çanakkale Boğazı'nı tek başına tutması iyi olmaz, özellikle de onları elde etmeleri için birlikte denizleri komuta eden İngiltere ve Amerika'yı kızdırdıysa. Gerçekte ihtiyacı olan şey, ne Çanakkale Boğazı'nın ne de ötesindeki denizlerin kendisine kapatılmayacağının, İngiltere ve Amerika garantisinde olmasıdır. "112

Constantine Brown ise Rus basını üzerinden yapılan taleplerin iki ülke arasında bir sinir harbine dönüştüğünü ve güçsüz Türkiye'nin, Moskova'nın tüm taleplerini kabul edebileceğini iddia etmiştir. ${ }^{113}$ Ayrıca, Moskova taleplerinin sadece Türkiye ve Rusya'yı ilgilendirdiğini belirterek İngiltere ve Amerika'nın probleme karışmaması gerektiğini belirtmiştir. Brown, Sovyetlerin birkaç aydır askeri hazırlıklar yaptığını ve Türkiye sınırlarındaki ordularının güçlendirildiğini belirtmiş, ancak kış aylarında Anadolu'da askeri operasyon yapmanın mümkün olmadığını dile getirerek sıcak ayların beklendiğini aktarmıştır. ${ }^{114}$

The Wilmington Morning Star gazetesinde Walter Lippmann, Sovyetler Birliği ile olan ilişkilerin, uzun süre iyi kalmayacağını ve kesinlikle daha da kötüleşeceğini belirterek Boğazlar konusunda yeniden düzenlemenin ikili müzakerelerle mi yoksa uluslararası anlaşmalarla mı gerçekleştirileceğine yönelik kararın acilen verilmesi gerektiğini belirtmiştir. ${ }^{115}$

Türk-Sovyet ilişkilerinde savaş olasıılı̆̆ının belirdiği bu dönemde bir başka dönüm noktası, İngiliz Dışişleri Bakanı Bevin'in 20 Şubat 1946 tarihinde Avam Kamarasında, Türkiye ile İngiltere arasında imzalanan Üçlü Paktın varlığını hatırlatması olmuştur. ${ }^{116} \mathrm{Bu}$ konuşma sonrası Amerikan basınında, olası bir Sovyet saldırısına İngiltere'nin cevap vereceği değerlendirmesi yapılmıştır. Örneğin, Constantine Brown 21 Şubat tarihli makalesinde İngiltere'nin bir saldırı durumunda Ankara hükümetine yardım etme vaadinin Moskova tarafindan bilindiğini ve İngiltere'nin Moskova'ya gözdağı verdiğini iddia etmiştir. ${ }^{117}$

The Evening Star gazetesi ise Brown ile aynı görüşü paylaşmamış, zayıflamış İngiltere'nin Türkiye'ye yardım edip edemeyeceğinin belirsiz olduğunu, aksine Rusya'nın askeri hazırlıklarını tamamladığını ancak Türkiye'nin "uydu devleti" olmak istemediğinden savaşacağını belirtmiştir.

\begin{abstract}
"Türkler, Amerikan ve İngiliz hükümetlerine, eşitsiz olanaklara rağmen sonuna kadar savaşacaklarını bildirdi. ...İsmet İn̈̈nü, konunun Çanakkale Boğazı'nda bir veya iki üs kurarak güvenlik isteyen Rusya meselesi olmadığını, ancak Rusların, Türkiye'nin tamamını siyasi ve askeri olarak kontrol etmeyi arzuladı̆̆ını belirtti. Rusya'nın, Avrupa'daki gelecekteki hareketleri, tamamen Amerikan ve İngiliz hükümetlerinin ne gibi bir tavır alacağına bă̆ll. Ĕger Rus beklentilerine göre, her iki batılı güç de konuşmalarını kısıtlarsa, ABD ve Ingiltere'nin hâlihazırda düşük prestijleri daha da acr çekecek ve Sovyet'in Panama Kanal ülkeleri ile ilgili görüşüne itirazda bulunma eğilimi tamamen ortadan kalkacaktır. ",118
\end{abstract}

Türkiye, Sovyetler Birliği'nin ilk taleplerine 1lımlı cevaplar vermiş ve bu tutum notalaşma sürecine yansımıştır. Ancak, Sovyetlerin taleplerinde 1srarcı oluşu, 1lımlı bir politika ile soruna çözüm getirilemeyeceğini kanıtlamış ve artık Türkiye, uluslararası hukuk ve teamüller ekseninde bir politika geliştirmeyi tercih etmiştir. Amerikan basını, Türkiye ile Sovyetler Birliği arasındaki bu sorunu Amerika ve İngiltere açısından da değerlendirmiştir.

\footnotetext{
${ }^{112}$ Walter Lippmann, “Bugün ve Yarın”, The Wilmington Morning Star, 31 Ocak 1946, s. 8.

${ }^{113}$ Constantine Brown, "Değişen Dünya”, The Evening Star, 3 Şubat 1946, s. 1.

${ }^{114}$ Constantine Brown, "Rusya Denize Ulaşmak İstiyor", The Evening Star, 10 Şubat 1946, s. 1.

${ }^{115}$ Walter Lippmann, "Bugün ve Yarın”, The Wilmington Morning Star, 20 Şubat 1946, s. 12.

${ }^{116}$ Gürün, age., s. 305.

${ }^{117}$ Constantine Brown, "Değişen Dünya”, The Evening Star, 21 Şubat 1946, s. 12.

${ }^{118}$ Constantine Brown, “Türk Problemi”, The Evening Star, 3 Mart 1946, s. 1.
} 
$\mathrm{Bu}$ değerlendirmelere göre, Sovyetlere karşı atılacak yanlış adımlar Anglo-Amerikan çıkarlarını da olumsuz yönde etkileyecektir.

\section{Sovyet Talepleri karşısında Amerikan Politikası: Missouri Savaş Gemisinin Türkiye'ye Gidişi ve Amerikan Basınındaki Tartışmalar}

Sovyet taleplerine yönelik ilk somut adım Amerikan Dışişleri Bakanlığının, Missouri savaş gemisinin, Türk büyükelçi Mehmet Münir Ertegün'ün cenazesini Türkiye’ye getirmek üzere yola çıktığını duyurmasıyla gelmiştir. Bu hareket Amerika'nın Sovyetlere karşı Türkiye'yi desteklediği yönünde alg1 oluşmasına neden olmuştur. ${ }^{119}$ ABD Dışişleri Bakanlığ ${ }_{1}$ basın sözcüsü Michael J. McDermott, yolculukta siyasi bir amaç olmadığını belirtse de Amerikan basını, Missouri savaş gemisinin Amerika'nın askeri gücünün bir hatırlatıcısı olarak hizmet ettiğini ve diplomatik bir anlam taşıdığını açılamıştır. The Wilmington Morning Star gazetesi Amerika'nın, Türkleri, kendi çıkarlarını savunmak için Sovyetler karşısında sağlam durmaya teşvik ettiğini ve Türklerin Amerikan imkânlarından yararlandığını iddia etmiştir. ${ }^{120}$ The New York Times gazetesi ise daha bu büyüklükte bir savaş gemisinin Boğazlara ilk kez girdiğini belirterek, ziyaretin Türk halkına moral vermenin yanında Yakın Doğu'daki barışa katkı sağlayacağını açıklamıştır. ${ }^{121}$

Amerika Dışişleri Bakanı Byrnes bir röportajında, Sovyetlerin toprak taleplerinin gayrı resmi bir şekilde ulaştırıldığını ve böyle bir şey varsa bile Amerika'nın haberi olmadığını vurgulayarak İstanbul ziyaretinin Sovyet talepleri ile ilgisi olmadığını söylemiştir. Röportaj sırasında gazetecilerin Potsdam Konferansı ile Molotov-Sarper görüşmeleri hatırlatması üzerine Byrnes, Rusya'nın Kars ve Ardahan için Türkiye'ye resmen talepte bulunmuş olsa bile, Amerika'nın bununla ilgili hiçbir bilgisi olmadığını söylemiştir. ${ }^{122}$

Toplumcu görüşleri ve Rusya'ya yakınlığıyla bilinen Henderson Daily Dispatch gazetesi Byrnes'in aksine Rusya'nın, Boğazlardan üs ile Kars ve Ardahan illerini açık açık istediğini hatta Başbakan Saraçoğlu'nun yabancı muhabirlerle yaptığı bir röportajda, Rusya'nın istediği toprakların müzakere dahi edilmeyeceği yönünde beyanat verdiğini aktararak Byrnes'ın açıklamalarının gerçeği yansıtmadığı belirtmiştir. ${ }^{123}$ The New York Times gazetesinde James B. Reston da kaleme aldığı makalesinde, Sovyetlerin sadece toprak istemekle kalmadığını aynı zamanda ABD ve İngiltere'ye bu bölgenin Sovyetlere dönmek zorunda olduğunu bildirdiğini açıklamıştır.

"Ruslar bölgeyi üç neden ile istemektedir. 1. Son savaşta bu bölgeler Rusya'nındır. 2. Kars ve Ardahan dağllk bölgelerinin hem Türkiye hem de Rusya savunması için stratejik öneme sahiptir. 3. Bu bölge İran ve Azerbaycan gibi petrol yatakları mevcuttur." 124

Missouri savaş gemisinin Türkiye ziyareti sonrası demokrat sekiz senatör, Başkan Truman'a bir mektup yazarak, Amerikan Hükümeti'nin Doğu Avrupa ve Pasifik politikalarını eleştirmişlerdir. "Panama Kanalı'nın ABD tarafindan özel olarak kontrol edilmesinde israr ettiğimiz sürece, Rusya'nın Çanakkale Boğazı'ndaki yaşamı ve ticareti için gerekli olan özel bir pozisyon taleplerine uygun şekilde itiraz edebilir miyiz?" sorusunu Başkan Truman'a aktararak

119 Şuhnaz Yılmaz, "Challenging the Stereotypes: Turkish-American Relations in the Inter-War Era", Middle Eastern Studies, (223-237), 2006, s. 230.

120 "Missouri Akdeniz Limanlarına Seyre Çıktı", The Wilmington Morning Star, 7 Mart 1946, s.13.

121 "Türkiye Ziyareti”, The New York Times, 12 Nisan 1946, s. 6.

122 “Byrnes, ABD’nin Sovyetlerin Türkiye Taleplerinden Az Bilgisi Olduğunu Açıkladı”, The Evening Star, 9 Mart 1946, s.2.

123 "Rus Birlikleri, Tam Donanımlı, İran'ın Başkentine Yakın”, Henderson Daily Dispatch, 13 Mart 1946, s.1.

${ }^{124}$ James B. Reston, “Amerika ve İngiltere Türk Topraklarına Yönelik Sovyet Talepleri Konusunda Bilgilendirildi”, The New York Times, 8 Mart 1946, s. 1. 
Amerika’nın Türk yanlısı tutumunu eleştirmişlerdir. ${ }^{125}$ Nobel Barış Ödülü sahibi uluslararası ilişkiler uzmanı Nicholas Murray Butler de ekonomik kalkınma anlamında Rusya'ya, İran'ın petrolünün yanı sıra Baltık ve Çanakkale'ye erişim hakkı verilmesini önermiştir. ${ }^{126}$

The Wilmington Morning Star gazetesi Rusya'nın tatmin olmayarak Boğazlarda bir savunma sistemi kurma önerisinde bulunduğunu belirtmiş ve çok önemli bir soruyu gündeme taşımıştır. "Ingiltere ve ABD böyle bir programa izin verebilir mi?." Gazete, BM Antlaşması yok olmadığı sürece izin verilemeyeceğini, Amerika'dan bir milyar dolar borç almak isteyen Rusya'ya olumsuz dönüş yapılmasını ve savaş sırasında Almanya'ya karşı kullanılması için Rusya'ya devredilen General Sherman tanklarının, İran'a ve Türkiye'ye yakın mesafedeki operasyonlarda kullanmaması konusunda uyarılmasını istemiştir. ${ }^{127}$

The Evening Star gazetesinde röportajı yayınlanan eski İngiltere Başbakanı Winston Churchill ise Sovyet taleplerinin BM Güvenlik Konseyinde çözülmesini önermiştir. Churchill, Sovyet hükümetinin Anglo-Amerikan teklifinden faydalanmaması halinde sorumluluğun tamamen kendine ait olacağını belirtmiştir. Churchill, Amerika ve İngiltere'nin Rusya'ya Potsdam Konferansı'nda önerilen şartların Sovyetlere yetmediğini ve toprak taleplerinde bulunduğunu belirtmiştir.

"Bu, boğazı açık tutmak değil, onu tek bir millete kapatma gücü vermektir. Bu, Amerika Birleşik Devletleri'nin Avrupa'nın büyük suyollarının, Tuna'nın, Ren'in ve çok sayıda farklı ülkeden akan diğer nehirlerin özgürlüğ̈̈ ilkesiyle uyumun kesilmesidir., ${ }^{28}$

Constantine Brown Sovyetlerin, taleplerini gerçekleştirmek için askeri harekât planladığını, Sovyet hükümetinin BM Güvenlik Konseyi’nin, yalnızca Moskova'nın isteklerine uygun olması durumunda işlevlerini yerine getirebileceği yönünde tehdit içeren bir açıklama yaptı̆̆ını belirtmiş ve Rusya'nın, İran ve Türkiye sınırlarında askeri hareketliliği tekrar başlatacağını iddia etmiştir. ${ }^{129}$

Sovyetlerin, Missouri savaş gemisi hamlesi sonrası problemlerini Amerika ile anlaşarak çözmesine yönelik bir dış politika oluşturmasına sebep olduğunu söyleyebiliriz. Özellikle 1946 Nisan-Mayıs aylarına denk gelen bu dönem Amerikan basınınca da tespit edilmiştir. Örneğin, The New York Times gazetesi, resmi olarak olmasa da Sovyetlerin Türkiye'den toprak taleplerinden sonra Sovyetlerin Türkiye ile ilişkilerini düzeltmek için girişimlere başladığını duyurmuştur. ${ }^{130}$

Amerika ile İngiltere'nin Türkiye yanlısı politikaları sonunda Molotov, Sovyet taleplerini azaltarak Boğazlarda istenilen bazı değişikliklerin sadece savaş durumlarında geçerli olmasını istemiştir. ${ }^{131}$ The Wilmington Morning Star, bu gelişmenin Sovyetlerin, Türkiye ile ilgili taleplerinde 1srar etmeyeceğine yönelik işaret olduğu yorumunda bulunmuştur. ${ }^{132}$

George Fielding Eliot, 6 Ağustos tarihinde kaleme aldığ 1 bir makalede Missouri zırhlısı İstanbul'a ulaştıktan sonra Sovyet gazetesi Pravda'nın Çanakkale Boğazı, Kars ve Ardahan, vb.

\footnotetext{
125 “Sekiz Bakandan Truman'a Mektup”, The Evening Star, 17 Mart 1946, s.5.

126 “Butler, Rusya'nın İran Petrolünü Alması ve Çanakkale’ye Girmesi Gerektiğini Söyledi”, The Evening Star, 25 Mart 1946, s.3.

127 "Rusya ve Barış", The Wilmington Morning Star, 19 Mart 1946, s. 4.

128 "Churchill, Sovyet'ten BM Güvenlik Konseyinin Sorunlarını Çözmesine İzin Vermesini İstedi”, The Evening Star, 16 Mart 1946, s.1.

${ }^{129}$ Constantine Brown, "Değișen Dünya”, The Evening Star, 29 Mart 1946, s. 8.

130 "Sovyetlerin, Türklerden Görüşme Talep Ettiği Bildirildi ”, The New York Times, 15 Nisan 1946, s. 3.

${ }^{131}$ Constantine Brown, "Değişen Dünya”, The Evening Star, 14 Mayıs 1946, s.8.

132 J. M. Roberts, "Haber Yorumları", The Wilmington Morning Star, 7 Temmuz 1946, s.6.
} 
hakkında neredeyse hiçbir şey yazmadığını belirtmiş ve Avrupa'nın gelecekteki huzurunu Amerika'nın sağlayacağını iddia etmiştir. ${ }^{133}$

Amerikan basını, Sovyetler Birliği’nin, Missouri zırhlısının ziyaretini kendilerine karşı planlanmış bir Anglo-Amerikan tutumu olarak algıladığını iddia etmiş, Türk yetkililerin ise bu ziyaret sonrası askeri ve ekonomik anlamda kendilerini güvende hissettikleri yönünde değerlendirmeler yapmıştır.

\subsection{Ağustos 1946 Tarihli Sovyet Notası Karşısında Amerikan Basınının Savaş Endişesi}

Türk-Sovyet ekseninde bu gelişmeler yaşanırken, 21 Temmuz 1946 seçimlerinde Türkiye ilk çok partili hayata geçiş deneyimini yaşamış ve yeni Hükümeti Recep Peker kurmuştur. ${ }^{134}$ Recep Peker Hükümeti kurulur kurulmaz, yeni hükümetin programını ve politikalarını bekleyen Sovyetler, 8 Ağustos 1946 tarihinde Boğazlar ile ilgili ilk notasın1 ${ }^{135}$ Türkiye'ye göndermiştir. ${ }^{136}$ The Evening Star gazetesi, Rusya'nın, Montreux Antlaşması'nın gözden geçirilmesini isteğinin imzacı bir devlet tarafından ilk kez talep edildiğini açıklamıştır. ${ }^{137}$ Sovyet hükümet gazetesi İzvestia notanın, İngiltere'ye ve ABD'ye de gönderildiğini duyurmuştur. ${ }^{138}$

Sovyetler bu nota ile Boğazlarda askeri üs taleplerini resmileştirmiştir. Amerikan basınında bu nota sonrasında olası bir savaş endişesinin hâkim olduğu görülmektedir. Örneğin, The Evening Star gazetesinde H. R. Knickerbocker'ın, yeni Başbakan Recep Peker ile yaptığı özel bir röportajda Başbakan Peker'e Sovyet talepleri ile ilgili bir gelişme olup olmadığına dair sorusuna, Peker, Rusya'yı yatıştırmaya çalışmayacaklarını, taleplerin reddedileceğini ve Türk ordusunun olası bir askeri hareket için seferber kalacağını açıklamıştır. ${ }^{139}$ Beklendiği gibi Recep Peker, 13 Ağustos tarihinde TBMM'de okuduğu Hükümet Programında Türkiye'nin toprak bütünlüğü konusundaki kararlılığ belirttikten sonra Boğazlar ilgili rejimin uluslararası antlaşmalara dayalı olduğunu ve Türk ordusunun daima hazır tutulacağını söylemiştir. ${ }^{140}$

Amerikan basını, Recep Peker Hükümeti'nin programı belli olduktan sonra Türk-Sovyet taleplerinin daha da gerginleşeceği ve sonunda bir savaş tehlikesiyle karşı karşıya kalınabileceği değerlendirmesinde bulunmuştur. Örneğin, Constantine Brown, Türk-Sovyet ilişkilerinin, Türk Hükümetinin tutumu sonrası Moskova'da yapılan basın ve radyo saldırıları ile gerginleştiğini ancak Türkiye'deki muhalefet ve mutsuz unsurların, Türkiye'nin

\footnotetext{
${ }^{133}$ George Fielding Eliot, "Güç Diplomasiyi Destekliyor”, The Evening Star, 6 Ağustos 1946, s.8.

${ }^{134}$ Recep Peker Hükümeti ile ilgili ayrıntılı bilgi için Bkz.: Kazım Öztürk, Türkiye Cumhuriyeti Hükümetleri ve Programları, Ak Yayınları, İstanbul,1968, s.281-310.

${ }^{135}$ Sovyetler, Boğazların bütün ticaret gemilerine, savaş gemilerinin ise sadece Karadeniz'e kıyıdaş devletlere daima açık olması, Karadeniz devletleri dışındaki ülkelerin savaş sırasında belli şartlar dışında geçişinin yasaklanması, Boğazlardan geçiş rejiminin Karadeniz devletlerince belirlenmesi ve Boğazların güvenliğinin Türk-Sovyet ortaklığı ile sağlanmasını talep etmiştir. Gürun, age., s. 306.

${ }_{136}$ Cemil Bilsel, "The Turkish Straits in the Light of Recent Turkish-Soviet Russian Correspondence", The American Journal of International Law, 1947 - (727-747), s. 735.

137 "Rusya, Montreux Sözleşmesinin Gözden Geçirilmesini İstiyor", The Evening Star, 11 Ağustos 1946, s.22.

138 "Rusya, Çanakkale Boğazı'nın Karadeniz Güçlerince Kontrol Edilmesini İstedi”, The Evening Star, 13 Ağustos 1946, s.1.

${ }^{139}$ H.R.Knickerbocker, "Yeni Türkiye Başbakanı, Orduyu Kızıllar İle İhtilaf Nedeniyle Harekete Geçirdi”, The Evening Star, 11 Ağustos 1946, s.22.

${ }^{140}$ TBMM, Zabıt Ceridesi, 8. Dönem, 1. Yasama Yı11, Cilt 1. (13.08.1946).
} 
topraklarının bir karışını yabancı güce vermeyeceği yönünde birleşerek, kararlılık gösterdiğini belirtmiştir. ${ }^{141}$

The Evening Star gazetesi Türkiye'nin, Sovyet taleplerini Montreux Sözleşmesinin sınırını aştığı gerekçesiyle reddedeceğini açıklamıştır. ${ }^{142}$ Gazete, Montreux Sözleşmesinde, askeri kullanımını etkileyen herhangi bir değişikliğin, Türkiye de dahil olmak üzere anlaşmanın dokuz imzacısının üçte ikisinin onaylaması durumunda değişebileceğini, İngiltere'nin, Sovyet taleplerine karşı olduğunu, Başbakan Peker'in de 1939'da İngiltere'yle yapılan anlaşmayı ve ayrıca Amerika ile işbirliğine dikkat çektiğini belirtmiştir. ${ }^{143}$

Constantine Brown, nota ile ilgili yaptığı değerlendirmede Washington'un konuyu bölgesel değil tüm dünyayı ilgilendiren bir konu olarak ele aldığını açıklamıştır. Brown, Akdeniz’i Rus gölü yapma arzusu güden Sovyet Rusya kuvvetlerinin Türkiye sınırlarında yoğunlaştığını, Türklerin bir ile dört ay arasında direnç gösterebileceğini bu sebeple olası bir savaşı engellemek için Ankara hükümetinin uzlaşmacı bir tutum benimsemesi gerektiğini belirtmiştir. Brown, Türkiye'nin BM Güvenlik Konseyine başvurabileceğini, Rusya'nın veto yetkisini kullanması durumunda ise Üçlü Pakt kapsamında İngiltere'nin Türklere askeri ve ekonomik yardımlar vermekle yükümlü olduğunu açıklamıştır. ${ }^{144}$

Sovyet notasına Amerika tarafından ilk resmi tepki 16 Ağustos tarihinde Dışişleri Bakanlı̆̆ Sekreteri Dean Acheson'ın, Amerika'nın Boğazlardaki herhangi bir Rus askeri genişlemesine karşı duracaklarını açıklaması ile gelmiştir. ${ }^{145}$ Sovyet notası Washington'da değerlendirilirken, Amerika'ya ait bir yolcu uçağının Yugoslavya üzerinden geçerken düşürülmesi SovyetAmerikan ilişkilerini kritik bir aşamaya getirmiştir. Amerika sağ kurtulan yolcuların iade edilmesi için BM Güvenlik Konseyi tarafindan "uygun eylem" ile yüzleşmemek adına Yugoslavya'ya 19 Ağustos 1946 tarihinde 48 saatlik bir nota vermiştir. Notada, "Dost bir ülkenin silahsız yolcu uçağı hakkında uyarıda bulunulmadan yapılan kasıtlı atışın, Amerika yasalarında ve insanlık ilkelerine karşı bir suç olduğu” belirtilmiştir. Amerikan basını bu gelişmenin Rusya ve Rusya bloğundaki ülkelere karşı son Amerikan eylemi olduğunu söylemiş ve batı güçleri ile Rusya arasındaki ilişkilerin savaştan sonra en düşük noktaya indirdiği belirtmiştir. ${ }^{146}$

Amerika'nın Sovyetlerle kısmen 1lımlı olan ilişkileri bu gelişme üzerine çok gergin bir hal almış, Sovyetlerin, Türkiye Boğazları üzerindeki bakışına da doğrudan etki etmiştir. Yugoslavya'ya verilen notadan sadece beş saat sonra Sovyetlerin, Boğazlar ile ilgili talebine cevap verilmiştir. $\mathrm{Bu}$ notada, Boğazların geçiş rejiminin Türkiye ile Karadeniz'e kıyıdaş devletler tarafindan belirlenmesi önerisinin uygun bulunmadığı ve Boğazların savunulması görevinin Türkiye'ye ait olduğu net bir şekilde bildirilmiş, bu notayı İngiltere'nin 21 Ağustos tarihli benzer notası takip etmiştir. ${ }^{147}$

\footnotetext{
${ }^{141}$ Constantine Brown, "Değişen Dünya”, The Evening Star, 13 Ağustos 1946, s.1.

142 "Sovyetlerin Çanakkale Boğazı Taleplerinin Türkiye Tarafından Reddedildiği Bildirildi”, The Evening Star, 14 Ağustos 1946, s.9.

143 “Türkiye Çanakkale Paktı'nı Değiştirmeye Hazır, Ancak Görüşme Talep Ediyor”, The Evening Star, 15 Ağustos 1946, s.10.

${ }^{144}$ Constantine Brown, "Değișen Dünya”, The Evening Star, 15 ve 19 Ağustos 1946, s.3.

145 "Kızıl İddiasına Karşı Türkiye Güçlü Duruyor", The Evening Star, 17 Ağustos 1946, s. 1.

146 "Sovyetler Birliği'nin Türkiye Taleplerine ABD Karşı Çıkıyor", The Wilmington Morning Star, 22 Ağustos 1946, s.1.

${ }^{147}$ Erkin, age., s. 297.
}

\section{History Studies}


Henderson Daily Dispatch, Amerika'nın Boğazlar ile ilgili talepleri reddettiğini açıklamış ${ }^{148}$ ve Rusya'nın bu stratejik suyoluna sahip olmak için güç kullanmakta 1srar etmesi durumunda "dünyada çok ciddi bir sorun olacağına" yönelik uyarının Sovyetlere iletildiği belirtmiştir. ${ }^{149}$ The Evening Star gazetesi, Amerika'nın, Sovyet talebini reddetmesinin temelinde Türkiye'nin egemenliği ve toprak bütünlüğü olduğunu vurgulamıştır. ${ }^{150}$

Amerika ve İngiltere'nin, Sovyetlere net bir şekilde karşılık vermesi üzerine Türkiye, 22 Ağustos tarihinde Dışişleri Bakanı Hasan Saka aracıllğıyla Sovyet Büyükelçiliğine cevabi notasını sunmuştur. ${ }^{151}$ Notada, Montreux Sözleşmesi'nin gemilerin geçişi konusundaki hükümleri üzerinde değişiklikler yapabileceğini ancak diğer taleplerin kabul edilmediği bildirilmiştir. ${ }^{152}$

Türkiye, Sovyetlere gönderdiği cevabi notayı 23 Ağustos'ta kamuoyuna açıklamıştır. Amerikan basını, Ankara'nın, Rusların Boğazlar hakkındaki korkularını anlamada zorluk çektiğini, Türkiye'nin, hangi ülkeden gelirse gelsin saldırganlığa karş1 ülkesini tüm gücüyle savunmakla ilgilendiğini belirtmiştir.

\begin{abstract}
"Dünyanın bütün uluslarının bir barış ve güvenlik çağı yaratmadaki katkılarını sağlamak için cesaretle rekabet ettikleri bir anda "savunmasın güçlendirmek" bahanesinin Birleşmiş Milletlerin amaçlarının varlığını inkar etmek olacaktır". ${ }^{53}$ "Karadeniz'deki Sovyetler Birliğ̈i'nin güvenliği için en kesin garanti, Boğazda imtiyazlı stratejik pozisyon arayışı içinde değil, güçlü bir Türkiye ile dostane ve güvene dayalı ilişkilerin restorasyonunda bulunur. Türkiye, bu mutlu dönemi başlatmak için tüm gücünü kullanmaya karar verdi, ancak bu anlamda çabasının kuzey komşusundan gelen eşit iyi niyetle yapılmasi gerekiyor. "I54
\end{abstract}

Henderson Daily Dispatch, taleplerin kabul edilmesi durumunda Rusya'nın Türkiye'yi sanal bir uydu haline dönüştüreceğini ${ }^{155}$ ayrıca bu isteklerin son Sovyet talebi olmayacağını belirtmiştir.

"Şüphe şüpheyi doğurur ve Ankara bir inç verirse Sovyetlerin bir mil alacağını ve nihayetinde kısa
sürede tüm bölgeye hâkim olacağından korkuyoruz. Kuşkusuz diğer güçler de Türkiye'nin Rusya'ya

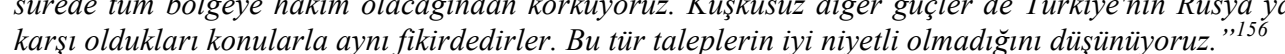

The Evening Star gazetesi, Moskova'nın önerilerinin BM'yi tamamen görmezden gelmekle birlikte Boğazlarda ortak bir Rus-Türk savunma sisteminin Türk topraklarında Sovyet üsleri anlamına geleceğini ve Boğazları tek başına Karadeniz güçlerine devretmenin Rusya'nın egemenliğine yol açacağını belirtmiştir. ${ }^{157}$ The Midland Journal gazetesi de Sovyet taleplerinin kabul edilmesi durumunda Kızıl askerlerin Türk topraklarının bir kısmını işgal etmesine izin vermek zorunda kalacağını belirtmiştir. ${ }^{158}$

\footnotetext{
148 “Boğazlar İle İlgili Rus Talebi ABD Tarafından Reddedildi”, Henderson Daily Dispatch, 21 Ağustos 1946, s.1.

149 "Rusya'nın Çanakkale'nin Kontrolü Konusundaki Notasına Türkiye Yanıt Verdi”, Henderson Daily Dispatch, 22 Ağustos 1946, s. 4.

150 "Rusya ve Boğazlar", The Evening Star, 22 Ağustos 1946, s.1.

${ }^{151}$ Gürün, age., s. 306.

${ }^{152}$ Uçarol, age., s. 1014.

153 “Ankara, Rusların Boğazlar Hakkındaki Korkularını Anlamada Zorluk Çekiyor”, The Evening Star, 24 Ağustos 1946, s.1.

154 “Türkler, Sovyetlerin Çanakkale Boğazı'ndaki Payına Olan Talebini Açıkça Reddetti”, Henderson Daily Dispatch, 24 Ağustos 1946, s.1.

155 "Çanakkale Durumu”, Henderson Daily Dispatch, 23 Ağustos 1946, s.1.

156 "Sonuncu Değil”, Henderson Daily Dispatch, 27 Ağustos 1946, s.4.

157 "Türkiye'nin Konumu”, The Evening Star, 25 Ağustos 1946, s.6.

158 "Çanakkale Boğazı Tartışması Belirsizdir; Milletler Barış İstiyor”, The Midland Journal, 30 Ağustos 1946, s.2.
}

\title{
History Studies
}


Walter Lippmann ise Boğazlar sorununun, Türkiye ya da "açma” sorunu olmadığını eğer böyle olsaydı Moskova'nın, Amerika'dan Boğazları güvence altına almak için onlara katılması için yalvarması gerektiğini belirterek Rusların asıl amacının Boğazları Anglo-Amerikan güce karşı kapatmak olduğunu söylemiştir.

\begin{abstract}
"Boğazları kim için kapattın? Çanakkale Boğazı'ndan geçerek Karadeniz'e girme kabiliyeti olan tek güç Anglo-Amerikalılar için. Rus görüşü açıtıtır: Ruslar, Türkiye ordusu ve hükümetini kontrol etmedikleri sürece, bir savaş durumunda, Ingiltere ve Amerika, yalnızca Çanakkale Boğazı'nı Karadeniz'e girmek için muazzam derecede üstün olan filolarlyla kullanmakla kalmayacak, aynı zamanda Türkiye'nin kuzeydeki istihkâmlarını, Sovyetler Birliği'nin yumuşak karnına yönelik havadan ve amfibi saldırllarına üs olarak kullanacaklardır.,"159
\end{abstract}

Amerika-Sovyet ilişkilerinin gergin olduğu bu dönemde, Amerika başka bir somut hamle daha yaparak Ege Denizinde, İngiliz, Amerikan ve Türk filolarının katılımıyla birleşik bir tatbikat gerçekleştireceğini duyurmuştur. Amerika Birleşik Devletleri Atlantik filosunun Franklin D. Roosevelt'i de içeren dokuz savaş gemisi ile Ege'de olduğu ve 18 Eylül'den sonra "Ingiltere Akdeniz Filosunun" da oraya gideceği açıklanmıştır. ${ }^{160}$ Amerika'nın tatbikat kararına Democrat The Key West Citizen gazetesi karşı çıkarak birkaç geminin varlığının Sovyet hükümeti üzerinde büyük bir baskı oluşturmayacağını iddia etmiş̧ir. ${ }^{161} \mathrm{Bu}$ tatbikat haberleri sürerken The New York Times, iki Türk savaş uçağının Rus topraklarına yakın bir bölgede düştüğü haberi yapılmıştır. ${ }^{162}$ Yine aynı gazetede Drew Middleton imzalı bir makalede Sovyetler Birliğinin bu gelişmeyi Karadeniz güçlerinin güvenliği için "doğrudan çelişki" olarak tanımladığını aktarmıştır. ${ }^{163}$

Amerika'nın tatbikat kararı ile askeri anlamda önlemler alması Amerikan Kongresinde muhalif seslerin çıkmasına neden olmuştur. Florida'lı Demokrat Senatör Pepper, Sovyet taleplerini savunan konuşmasında Amerika'nın, Çanakkale'den serbest geçiş hakkını reddetmesinin, Stalin'in Panama Kanalı'nı kullanmamızı engellemekten daha fazla anlam içerdiğini söylemiştir. Pepper, ideolojiler yarışmasına yol açan bir dış politikanın yalnızca insan toplumunun nihai bozulmasına yol açacağını iddia emiştir. ${ }^{164}$

Amerika'nın hem siyasi hem de askeri anlamda attığ adımları umursamayan Sovyetler, 24 Eylül tarihinde bir nota ile taleplerini tekrarlamış, Boğazların ortak savunulmasını, Potsdam Konferansı'nda belirtildiği gibi ülkeler arası doğrudan görüşmelerin gerçekleştirilmesini ve toplanacak konferansta Montreux Sözleşmesi'nin ayrıntılı olarak tartışılmasını istemiştir. ${ }^{165}$ Ayrıca, 22 Ağustos tarihli Türk notasının kusurlu olduğu iddia ederek, Konferans öncesi hükümetler arasında doğrudan müzakereler yapılmasını istemiştir. ${ }^{166}$

Sovyetlerin notası sonrası Amerikan basını, Amerika ve İngiltere'nin, Boğazlar bölgesine yapılacak herhangi bir Rus genişlemesine ve Sovyetlerin doğrudan müzakere isteğine karşı sert durulması gerektiğini belirtmiştir. Sovyet taleplerini reddeden 22 Ağustos'taki Türk notasının

\footnotetext{
${ }^{159}$ Walter Lippmann, “Sovyet Hükümeti, Sorunun Çözülmesi Gereken Yeri Açıcça Ortaya Koydu”, The Wilmington Morning Star, 6 Eylül 1946, s.13.

160 “İngiliz, Amerikan ve Türk Filoları Ege Denizi'nde Birleşik Tatbikat Gerçekleştirecek”, The Evening Star, 4 Eylül 1946, s.10.

161 "Savaş Gemileri ve Ziyaretler”, The Key West Citizen, 13 Eylül 1946, s.2.

162 "Türk Uçakları Rusya'da Kayboldu”, The New York Times, 10 Eylül 1946, s.16.

163 Drew Middleton, "Rusya, Türkleri, Boğazlar Konusunda Yabancı Yardımından Kaçmaları Konusunda Uyardı", The New York Times, 29 Eylül 1946, s. 1.

164 “Pepper, Boğazların Kullanımına Yönelik Sovyet Teklifini Savunuyor”, The Evening Star, 8 Eylül 1946, s. 22.

${ }^{165}$ Erkin, age., s. 303.

166 “Ruslar İkili Oynuyor”, The Wilmington Morning Star, 30 Eylül 1946, s.1.
} 
Amerikan ve İngiliz destek güvencelerine dayandığı hatırlatılarak Ankara'daki AngloAmerikan elçilerinin yeni Rus notasına cevaben bu desteğin hatırlatılması istenmiştir. ${ }^{167}$

The Evening Star gazetesi Sovyet notası sonrası Türk ordusunun alarma geçtiğini duyurmuştur. Türk yetkililere dayandırılan haberlerde, Türkiye'nin "beş dakika içinde bir savaşa girmeye hazır ve haklarını savunmaya kararlı" olduğu açıklanmıştır. ${ }^{168}$

Constantine Brown, Ankara ve Moskova arasındaki asıl meselenin, Türkiye'nin bir Rus uydusu haline gelip gelmeyeceği veya egemenliğinden yararlanmaya devam edip etmeyeceği olduğunu belirtmiştir. Brown, Türkiye Cumhuriyetinin kurulduğundan beri, sloganının "yaşa ve yaşat" olduğunu, komşularından hiçbirinin topraklarında talepte bulunmadığını ve halkın tam bağımsızlığını korumak için fanatik bir eğilim içinde olduğunu belirtmiştir.

\begin{abstract}
“Ankara hükümeti kartlarını Washington, Londra ve Moskova'daki masanın üstüne koydu. BM ile işbirliği yapmak ve bu organizasyonun yaratıldığı standartlara uyma konusunda endişelidir. Ancak, Güvenlik Konseyi'nin hantal mekanizmalarının bir istila durumunda harekete geçmesini beklemeden herhangi bir saldırganı kovma konusunda kararlı olduğunu bildirdi. ...Ankara hükümeti, herhangi bir saldırganın faaliyete geçmeye karar vermeden önce iki kez düşüneceğini umuyor. "169
\end{abstract}

Brown, Ankara hükümetinin bu kararlı tutumuna rağmen, Rus gücüne süresiz olarak dayanamayacağını ve yalnız kalırsa, tahrip olacağını ve bir başka Rus ülkesi haline geleceğini iddia etmiştir. ${ }^{170}$ Ancak, her şeye rağmen askeri anlamda gerginleşen ortam karşısında Türkiye'deki muhalefet ve iktidarın aynı çizgide birleştiğini, örneğin Demokrat Fuad Köprülü’nün, “ister kırmızı isterse beyaz olsun, totaliter fikirlere" karşı çıktığını aktarmıştır. ${ }^{171}$

The Evening Star gazetesinde Dorothy Thompson, Amerika Boğazlar için savaşmay planlıyorsa, bunun açıkça belirtilmesini, Sovyetlere diğer taleplerin ancak bu şekilde kabul ettirilebileceğini iddia etmiştir. ${ }^{172}$ The Key West Citizen, Sovyetlerin isteklerde 1 srar etmesi durumunda Türkiye'nin savaşabileceğini kaydetmiştir. ${ }^{173}$

The New York Times, Sovyet Pravda gazetesinde çıkan bir makaleye yer vermiştir. Söz konusu makalede Sovyetlerin Amerika ile Türkiye arasındaki yaklaşmanın "çarpık" olarak tanımladığını, Türk politikasının İngiltere tarafından kontrol edildiğini ve uygun görürse Amerika tarafından onaylandığını aktarmıştır. Pravda gazetesi Amerikan desteğini Türk bağımsızlığına müdahale olarak değerlendirmiştir.

"Biz dolar diplomasisi ve dolar demokrasisi görüyoruz. Ancak burası dolar coğrafyası değildir. Türkiyenin bağımsızlı̆̆ı Anglo-Amerikan himayesi altında nasıl mümkün olacak? Anglo-Amerikan harçlı Türk pudingi.,"174

Türkiye'nin kararlı tutumu, gerektiğinde Sovyetler ile savaşabileceğini açıklaması Sovyetler tarafından Amerikan ve İngiliz güvencesine dayandırılmıştır. Özellikle askeri tatbikatlar, ekonomik yardım girişimleri ve Missouri zırhlısının Türkiye ziyareti Sovyetleri bu görüşe iten nedenleri oluşturmaktadır.

\footnotetext{
167 “Kızıllar, Çanakkale Boğazı Taleplerini Yeniliyor”, The Wilmington Morning Star, 29 Eylül 1946, s.1.

168 "Türkiye Ordusu, Kızıl Talebinden Sonra Alarma Geçti”, The Evening Star, 29 Eylül 1946, s.1.

${ }^{169}$ Constantine Brown, "Değişen Dünya”, The Evening Star, 2 Ekim 1946, s.2.

${ }^{170}$ Constantine Brown, "Türkler Herhangi Bir Rus Egemenliğini Engellemeye Kararlı”, The Evening Star, 6 Ekim 1946, s.1.

171 "Ruslar, Türkiye İle Doğrudan Görüşme Yapmayı Planlıyor”, The Evening Star, 11 Ekim 1946, s.2.

172 Dorothy Thompson, The Evening Star, 16 Ekim 1946, s.3.

173 “ABD, Türkiye İle İlişkide Olan Rusya'ya Karşı Çıkıyor”, The Key West Citizen, 12 Ekim 1946, s.1.

174 “Ruslar, ABD’nin Türklere 'Çarpık' Desteğini Görüyor”, The New York Times, 21 Ekim 1946, s. 15.
} 


\section{Türk-Sovyet Anlaşmazlığının Sonu ve Truman Yardımı}

Sovyetlerin son notasına Amerika 9 Ekim tarihinde Moskova'da bulunan Büyükelçi Walter Bedell Smith aracılığıyla karşılık vermiştir. ${ }^{175}$ Cevapta, Boğazların sadece Türkler tarafindan savunulacağı, Potsdam'da ikili görüşme değil fikir alış-verişi yapılacağına dair anlaşıldığı, Amerika ve İngiltere'nin konferansa katılacağı, Boğazlarda özel bir rejim uygulanmayacağı ve Boğazlara yönelik bir saldırının BM Güvenlik Konseyince tartışılacağ 1 belirtilmiştir. ${ }^{176}$ Amerikan notası sonrası The Key West Citizen, Boğazlar anlaşmazlığında Amerika'nın Türkiye tarafını seçtiğini açıklamıştır. ${ }^{177}$

Türkiye; Amerika ve İngiltere'den aldığı destek ile Sovyetlere cevabını 18 Ekim tarihinde göndermiş ve Karadeniz devletlerine özel bir rejim uygulanamayacağını bildirmiştir. ${ }^{178}$ Türkiye, her üç devletin Türkiye ile müzakere etmesine yönelik görevin tamamlandığını bu saatten sonra Montreux Antlaşması'nın tadil edilmesi yönünde adımların atılmasını istemiştir. ${ }^{179}$

Türkiye'nin notası Amerikan siyaseti ve basını tarafından iyi karşılanmıştır. Henderson Daily Dispatch, Rusya'nın ikinci önerilerinin de açıkça reddedildiğini ve Montreux Sözleşmesinin gözden geçirilmesi için Rusya'nın ikili görüşmelerine Türkiye tarafından açıkça karşı çıkıldığını belirtmiştir. ${ }^{180}$ The Evening Star gazetesi ise Türkiye'nin, Boğazlar bölgesindeki taleplere direndiği için 50.000.000\$'a kadar kredi ile ödüllendirildiğini duyurmuştur. ${ }^{181}$

Resmi açıklama Dışş̧leri Bakanı Byrnes tarafından yapılmış ve "Amerika Birleşik Devletleri'nin tüm milletler için özgürlük ve tüm milletler arasında dostluk anlamına geldiğini”" söylemiş, Amerika'nın özel ittifaklar fikrini reddetmeye devam edeceğini belirtmiştir. ${ }^{182}$ Byrnes'in açıklamasından sonra The Evening Star gazetesi İngiltere Dışişleri Bakanı Bevin'in Rusya'nın taleplerine karşı çıkan açıklamasını yayınlamıştır. ${ }^{183}$ Constantine Brown, Amerika ve İngiltere'nin tutumu sonrası Türk hükümetinin ordunun verimliliğini arttırmak için gereken savaş malzemesi talebinde bulunduğunu ve bu isteğin şu anda Washington ve Londra'da dikkate alındığını açıklamıştır. ${ }^{184}$

\footnotetext{
175 “ABD Muhalefeti Yeniden Düzenlendi”, The Wilmington Morning Star, 12 Ekim 1946, s.1.

${ }^{176}$ Uçarol, age., s. 1014 ve Gürün, age., s. 307-308.

177 “Türkiye'yi Tercih Ediyor”, The Key West Citizen, 10 Ekim 1946, s.1.

178 Türkiye notada ikili görüşmelere karşı olduğunu açıklamasına rağmen Türk iç politikasında ikili görüşme isteyenler ve istemeyenler olarak bir kamplaşma oluşmuştur. Ancak, ikili görüşmelerin kabul edilmesinin Sovyetlerle yapılacak görüşmeler esnasında Bulgaristan ve Romanya'nın da görüşmelere bir oldubittiyle katılması sonucunu doğurabileceği, Karadeniz devletlerinin kendi aralarında anlaştığı şeklinde algılanabileceği ve Sovyet tezinin kabulü anlamına geleceğinden olumlu karşılanmamıştır. (Gürün, age., s. 308.)

179 "Talepler Reddedildi", The Wilmington Morning Star, 21 Ekim 1946, s.1.

180 "Çanakkale Boğazı İle İlgili Sovyet Talepleri Yine Reddedildi”, Henderson Daily Dispatch, 19 Ekim 1946, s.4.

181 “ABD, Türklere 25-50 Milyon Kredi Sağladığını Bildirdi”, The Evening Star, 20 Ekim 1946, s.6. 25.000.000 \$'1 İhracat-İthalat Bankası'ndan, Türkiye hükümetine devretmek yerine, kredi verme işleminde genel prosedür, banka Amerikalı üreticilere Türk hükümeti siparişlerinde 25.000.000 \$'lık destek garantisi verecektir. Ürünlerini Türkiye'ye satan Amerikalı üreticilerden, Türk hükümetine eşit miktarda kredi açarak riskin bir kısmını paylaşmaları istenecek.(“ABD, Türklere 25-50 Milyon Kredi Sağladığını Bildirdi”, The Evening Star, 20 Ekim 1946, s.6.)

182 Constantine Brown, "Değişen Dünya", The Evening Star, 21 Ekim 1946, s.6.

183 "Potsdam'ı Uygula Ya Da Yeni Anlaşma İmzala”, The Evening Star, 22 Ekim 1946, s.1.

${ }^{184}$ Constantine Brown, "Değişen Dünya”, The Evening Star, 22 Ekim 1946, s.8.
} 
Amerika ve İngiltere tarafından bir hamle de Amerikan Donanmasına ait savaş gemilerinin, hem Türk hem de Yunan limanlarını ziyaret edeceğini açıklaması olmuştur. ${ }^{185}$ The Wilmington Morning Star gazetesi Amerikan Deniz Kuvvetlerinin Türk sularına gönderilmesinin Boğazların, Kızıl Ordu'nun egemenliğine girmesini engellemek için gerçekleştirildiğini, bu hareket ile Amerika'nın Türkiye'nin toprak bütünlüğünü ve bağımsızlığını garanti etmede kararlı olduğunu açıklamıştır. ${ }^{186}$

Sovyetlere karşı alınan bu önlemler sonrası, olası bir savaş durumundan kaçınan Cumhurbaşkanı İsmet İnönü Mecliste yaptığı konuşmada, iki ülke arasındaki ilişkilerin BM ruhu ve şartları üzerine kurulması durumunda Türkiye ile Rusya arasında dostluğun önünde engel kalmayacağını söylemiştir. İnönü, Türkiye'nin diş ilişkilerinde en büyük sorunun güvenlik olduğunu belirtmiş, Montreux sözleşmesini revize etmeye istekli olduklarını ancak tüm ulusların çıkarlarını göz önünde bulundurmak zorunda olduklarını açıklamıştır. ${ }^{187}$

Montreux Antlaşması'nın hükümlerinde yapılacak değişiklik amacıyla toplanması planlanan Konferansa yönelik ilk adım İngiltere tarafında atılmıştır. Konferans çağrısı 23 Aralık tarihinde İngiliz Büyükelçi Maurice Peterson tarafından sözlü olarak Moskova'ya iletilmiştir. ${ }^{188}$ Constantin Brown, İngilizlerin bu ani çıkışını değerlendirdiği makalesinde, İngilizlerin, Avrupa'daki Rus batı hattını tanıması karşılı̆̆ında Sovyetler, Boğazlar ile Kars ve Ardahan'daki saldırgan eylemlerden kaçınacağını vaat etmesi üzerine İngilizlerin konferans istediğini iddia etmiştir. Brown, her iki ülke de Asya'da üstün bir rol oynamak için üçüncü bir gücün müdahalesi veya girişimlerinden kaçınarak Uzak Doğu'daki mevcut durumun korunmasını kabul edeceğini iddia etmiştir. ${ }^{189}$ İngilizlerin girişimi sonuçsuz kalmış Rusya ne bir konferans talebinde ne de Boğazlar üzerindeki iddialarını yenileyen istekte bulunmuştur.

Amerikan basınını 1947 yılının ilk çeyreğinde Komünizm tehdidi altında olduğu düşünülen Türkiye ve Yunanistan'a yardım konusu meşgul etmiştir. Amerikan basınındaki ortak görüş her ne kadar savaşa katılmasa da Türkiye'nin ağır baskı altında kalması nedeniyle ekonomik olarak etkilendiği yönündedir. Ekonomik yardımın içeriği incelendiğinde ise Türk ordusunun bir kısmının terhis edilebilmesi için gerekli olan düzenlemelerin yapılması ve insan gücünün ekonomik alana bir an önce entegresinden oluşmaktadır. Türkiye'ye yapılması planlanan yardımın Yunanistan'a yapılandan daha az olacağı tartışmaların ilk gününden açıklanmıştır.

Türkiye ve Yunanistan'a yapılacak yardım ile ilgili plan 12 Mart 1947 tarihinde Başkan Truman tarafindan Kongreye sunulmuş ve hemen Rusya tarafindan saldırıya uğramıştır. ${ }^{190}$ The Wilmington Morning Star, Türkiye ve Yunanistan'a 400.000.000 dolar şeklinde kullandırılacak yardımların Komünizmle mücadele için verildiğini açıklamıştır. ${ }^{191}$

\footnotetext{
185 Bugünkü Donanma açıklamasında 27.000 tonluk uçak gemisi Randolph, hafif kruvazör Fargo ve destroyer Perry'nin katılacağı belirtildi. (“3 ABD Savaş Gemisi Yunan ve Türk Limanlarını Ziyaret Edecek”, The Evening Star, 8 Kasim 1946, s.1.)

${ }^{186}$ The Wilmington Morning Star, 26 Mart 1947.

187 “Türk-Sovyet Barış1 Mümkün”, The Wilmington Morning Star, 2 Kasım 1946, s.2.

188 “İngiltere, Boğazlar Paktı İmzalayıcılarını Konferansa Çağırıyor”, The Evening Star, 24 Aralık 1946, s.4.

${ }^{189}$ Constantine Brown, "Stalin, İngilizlerle Geniş Bir Çözüme Hazır Olduğunu Bildirdi”, The Evening Star, 20 Şubat 1947, s.2.

190 Gürun, age., s. 308.

${ }^{191}$ The Wilmington Morning Star, 30 Mart 1947, s. 1.
}

\section{History Studies}


Truman Doktrini/Yardımı olarak adlandırılan bu gelişme Amerikan basınınca uzun süre işlenmiştir. The Evening Star, Truman'ın önerilerinin Türkiye'de "mutlak sevinç” ile karşılandığını ve askeri anlamda bir rahatlamaya neden olacağını açıklamıştır. ${ }^{192}$

Amerikan Kongresi'ndeki tartışmaların basına yansımaları incelendiğinde Senatörler arasında kesin ve net bir birliktelik olmadığı ancak tamamının tasarı amacını Komünizm ile mücadele olarak tanımladığı görülmektedir. Ayrıca, sadece Yunanlılara yardım edilmesini savunan Demokratlara karşılık Cumhuriyetçiler sadece bir ülkeye yardım edilmesi durumunda ikisinin de toprak bütünlüğünün tehlike altında kalacağını savunmuşlardır.

The Wilmington Morning Star gazetesinde Virgil M. Pinkley imzalı makalede Türkiye Cumhurbaşkanı İsmet İnönü’ye ait bir röportaj yayınlanmıştır. İnönü, “Çanakkale Boğazı'nın geleceğini nasıl öngörüyorsunuz ve Türkiye herhangi bir gelecek konferansa boğazlardan geçişle ilgili herhangi bir özel plan sunmayı teklif ediyor mu?" sorusuna şu cevabı vermiştir.

\begin{abstract}
"8 Ăgustos ve 18 Ekim 1946 tarihli Sovyet hükümetine gönderilen notalarda belirtildiği gibi, Türkiye, Boğazların mevcut rejiminin, tüm taraflara memnuniyet vermek için tasarlanabilecek en adil ve en dengeli sistem olduğuna inanmaktadır. Herhangi bir iktidar bu rejimle ilgili herhangi bir şikâyet sebebi bulursa, bu iktidar, Montreux sözleşmesinin öngördüğü usule göre değisşiklik yapmak için her zaman bir konferansin yapılmasinı isteyebilir." 193
\end{abstract}

Amerikan Kongresi, Truman Yardımını 22 Mayıs 1947 tarihinde kanunlaştırmış ve Türkiye ile Sovyetleri siyasi, ekonomik ve askeri yol ayrımına itmiştir. ${ }^{194}$ Truman yardımının hemen ardından Marshall yardım planları Amerika ile Türkiye arasındaki ilişkileri daha da belirgin hale getirmiştir. ${ }^{195}$

Türkiye, Amerika'dan aldığı destekle Sovyet tehdidini bertaraf etmiş, özellikle Truman ve Marshall yardımları ile Sovyetlere karşı güvenliğini sağlamıştır. Sovyet yayılması ve tehlikesine karşı 1949 yılında kurulan Kuzey Atlantik Antlaşması Örgütü(NATO)'ne katılmak için Türkiye'nin 1950 yılında yaptığı müracaat kabul edilmemiştir. ${ }^{196}$ Ancak iki kutup arasındaki ayrımı belirgin şekilde ortaya çıkaran Kore Savaşı sonucunda Türkiye ve Yunanistan, NATO tarafindan örgüte davet edilmiş, Türkiye 18 Şubat 1952 tarihinde Antlaşmayı kabul etmiş ve böylece yedi yıldır Sovyetler tarafından tehdit edilen güvenliğini, Batı güvenlik kanadında yer alarak bertaraf etmeyi başarmıştır. ${ }^{197}$

Türkiye'nin NATO üyeliği Sovyet donanmasının Karadeniz'de kalmasına sebep olduğu düşüncesiyle önemli olduğu değerlendirilmektedir. ${ }^{198}$ Türkiye'nin NATO'ya üyeliği ile başlayan Batı-Türkiye yakınlaşmasının etkisi ve bunun dışında 1953 yılında Stalin'in ölümü, Sovyetlerin Türkiye üzerindeki baskısını tamamen ortadan kaldırmasına sebep olmuştur. Sovyetler, bunun bir göstergesi olarak, 10 Mayıs 1953 tarihinde bir notayla Boğazlar, Kars ve Ardahan ile ilgili artık bir talepleri olmadığını bildirmişlerdir. ${ }^{199}$

\footnotetext{
192 "Türkler Memnun”, The Evening Star, 13 Mart 1947, s.5.

193 "Türkiye, ABD Nakit Yardımını Ordusuna Kullanacak", The Wilmington Morning Star, 13 Mayıs 1947, s.2.

194 Gürün, age., s. 309.

${ }^{195}$ Hale, age., s. 116-117.

${ }^{196}$ Süleyman Ekici ve Abdulkadir Baharçiçek, “NATO’ya Üyelik Sürecinde Türkiye ABD İlişkileri”, Birey ve Toplum, C.6, Say1 11, (149-166), s. 158.

${ }^{197}$ Uçarol, age., s. 1026.

${ }^{198}$ Bruce R. Kuniholm, “Turkey and the West” Foreign Affairs, Vol. 70, No. 2, 1991, Spring, (34-48), s. 34.

199 George Lenczowski, "Evolution of Soviet Policy Toward the Middle East", The Journal of Politics, Vol. 20 No. 1, 1958, February, (162-186), s. 172.
}

\title{
History Studies
}




\section{Sonuç}

Amerikan basını savaş arifesinde Türk-Sovyet yakınlaşmasını ilgiyle takip etmiş ve Türkiye'yi Sovyet Rusya ile büyük güçler arasında köprü kuracak en önemli devlet olarak görmüştür. 1939 yılındaki Türk-Sovyet görüşmelerinin sonuçsuz kalması üzerine Türkiye Boğazların “Gardiyanı/koruyucusu” olarak tanımlanmıştır.

Amerikan basını, Türk-Sovyet Saldırmazlık Paktının iptal edilecek olmasını şaşkınlıkla karşılamıştır. Türkiye'nin, Montreux Antlaşması şartlarında değişiklikleri kabul eden uzlaşmacı tavrı ve özellikle Amerika'nın barış ve savaş sırasında Karadeniz'i istediği gibi kullanma ve Sovyetleri Karadeniz'e hapsetme politikasına karşı çıkmaması sebebiyle desteklendiği söylenebilir. Ayrıca, BM olgusu ve bu örgütün dünya barışını koruyan, "devletler üstü” bir kuruluş olduğu ve her türlü anlaşmazlığın çözüm merciinin burası olması gerektiğine sık sık atıfta bulunularak Sovyetlerin barışı bozan, Türkiye'nin ise uzlaşmacı barış yapan taraf olduğu dile getirilmiştir.

Sovyetlerin 8 Ağustos 1946 tarihinde Boğazlar ile ilgili ilk notasından başlayarak talepleri konusunda geri adım atmaması hatta toprak taleplerine varan istekleri, Sovyet Rusya'nın BM sözleşmesini umursamadığ şeklinde bir alg1 oluşmasına sebep olmuştur. Bu alg1 sonucunda Amerikan basınında hiç kesilmeyen bir savaş endişesinin hâkim olduğu görülmektedir. Amerikan basınının, Komünist Rusya'nın- emperyalist emellerle- Türk topraklarına göz diktiği ve olası bir Türk-Sovyet savaşı algısı oluşturarak, Komünizm ile mücadelede Türk-Sovyet gerginliğinden yararlandığını söylemek de mümkündür.

Amerikan basınında bu süreçte Sovyetlerin, Panama Kanalını örnek göstererek Boğazlardaki taleplerini haklı çıkaracağı endişesi hâkim olmaya başlamıştır. Bu yazılar incelendiğinde, Amerikan siyaseti ve özellikle Başkan Truman'ın basını kullanarak doğal suyolları ile insan yapımı kanallar arasında bir ayrım yaptığı göze çarpmaktadır. Amerika'nın bu tavrı Türk-Sovyet anlaşmazlığında önemli bir dönüm noktası olmuştur. Bu söylem ile Sovyetlerin Boğazlar üzerindeki tüm talepleri bertaraf edilmiş ve bu istekler BM sözleşmesine aykırı olarak değerlendirilmiştir.

Türkiye'nin, Sovyet taleplerine ne olursa olsun karşı1lı vereceği anlaşıldıktan sonra Amerika'nın Türk-Sovyet anlaşmazlığı karşısında daha net bir tavır aldığını söylemek mümkündür. Amerikan basınında süreklilik gösteren yazılar takip edildiğinde bu durum açıkça görülmektedir. Missouri zırhlı gemisinin Türkiye'yi ziyareti ile başlayan bu yakınlaşma süreci, Ege Denizindeki tatbikat kararıyla devam etmiştir. Truman ve Marshall Yardımları ile ise Türkiye Sovyet tehdidi karşısında önemli bir dayanak elde etmiştir.

\section{Kaynakça}

\section{a. Kitap ve Makaleler}

ARALOV, Semiyon İ., Bir Sovyet Diplomatının Türkiye Hatıraları, Cumhuriyet Yayınları, İstanbul, 1997.

ARMAOĞLU, Fahir, 20. yy Siyasi Tarihi (1914-1918), İş Bankası Yayınları, Ankara, 1993.

ATABEY, Figen, “Monterux Konferansı'ndan İkinci Dünya Harbi’ne Türk-Sovyet İlişkileri”, Avrasya Uluslararası Araştırmalar Dergisi, Cilt:2, S.4, Ocak 2014.

AYDIN, Mustafa, "İkinci Dünya Savaşı ve Türkiye”, Türk Dış Politikası, Ed. Baskın Oran, İletişim Yayıncılık, İstanbul, 2009, s. 399-475. 
BİLSEL, Cemil, "The Turkish Straits in the Light of Recent Turkish-Soviet Russian Correspondence" The American Journal of International Law, s. 727-747, 1947.

CEBESOY, Ali Fuat, Moskova Hâtıraları (21.11.1920-2.6.1922), Temel Yayınları, İstanbul, 2002.

EKİĊ, Süleyman, ve Abdülkadir Baharçiçek, "NATO'ya Üyelik Sürecinde Türkiye ABD İlişkileri” Birey ve Toplum, C.6, Sayı 11, s.149-166, 2016.

ERKİN, Feridun C., Türk Sovyet İlişkileri ve Boğazlar Meselesi, Başnur Matbaası. Ankara, 1968.

Ertem, Barış, “Türkiye Üzerindeki Sovyet Talepleri ve Türk-Sovyet İlişkileri (1939-1947)”, Uluslararası Sosyal Araştırmalar Dergisi, Vol. 3, 11, Bahar, 2010.

FOX, Annette B., The Power of Small States Diplomacy in World War II. The University of Chicago Press, Chicago, 1959.

GÖKÇEN, Salim, "Ankara - Moskova İlişkilerinin Gelişimi ve 1925 Dostluk ve Saldırmazlık Antlaşması", Uluslararası Karadeniz İncelemeleri Dergisi, 2007, s.123.

GÖNLÜBOL, Mehmet ve Cemal Sar, Atatürk ve Türkiye'nin Dlş Politikası (1919-1938), Atatürk Araştırma Merkezi Yayınları, Ankara, 2013.

GÖNLÜBOL, Mehmet ve Cemal Sar, "1919-1938 Yılları Arasında Türk Dış Politikası”, Olaylarla Türk Dış Politikası 1919-1995, Ed. M. Gönlübol, Siyasal Kitabevi, Ankara, 1996, s. 3-126.

GÜRÜN, Kamuran, Türk-Sovyet Illişkileri (1920-1953), Türk Tarih Kurumu Yayınları, Ankara, 2010.

HALE, William, Türk Dış Politikası 1774-2000, Mozaik Yayınları, İstanbul, 2003.

KARABEKİR, Kazım, İstiklal Harbimiz, Yapı Kredi Yayınları, İstanbul, 2014.

KUNIHOLM, Bruce R., "Turkey and the West", Foreign Affairs, Vol. 70, No. 2, s. 34-48, Spring 1991.

KURAT, Yuluğ T., “Kahire Konferansı Tutanakları (4-7 Aralık 1943) ve Türkiye'yi Savaşa Sokma Girişimleri”, Belleten, C.XLVII, Sayı 185, s. 298-335, 1983.

LENCZOWSKİ, George, "Evolution of Soviet Policy Toward the Middle East", The Journal of Politics, Vol. 20 No. 1, s.162-186, February 1958.

ÖZERSOY, Kudret, "Montreux Boğazlar Sözleşmesi”, Türk Dış Politikası, Ed. Baskın Oran, İletişim Yayıncılık, İstanbul, 2009, s. 370-384.

ÖZTÜRK, Kazım, Türkiye Cumhuriyeti Hükümetleri ve Programları, Ak Yayınları, İstanbul, 1968.

ROBERTS, Geoffrey, "Moscow's Cold War on the Periphery: Soviet Policy in Greece, Iran, and Turkey, 1943-8.", Journal of Contemporary History, Vol. 46, No. 1, s. 58-81, January 2011.

SELEK, Sabahattin, Anadolu İhtilali, Burçak Yayınevi, İstanbul, 1968.

SONYEL, Salahi R., Türk Kurtuluş Savaşı ve Dış Politika II, Türk Tarih Kurumu Yayınları, Ankara, 2003. 
SOYSAL, İsmail, "1925 Türk Sovyet Saldırmazlık Paktı'na Ekli Gizli Kalmış Bir Belge: Çiçerin'in Mektubu", IX. Türk Tarih Kongresi, 21-25 Eylül 1981.

SOYSAL, İsmail, Tarihçeleri ve Açılklamaları ile Birlikte Türkiye'nin Siyasal Andlaşmaları C.I (1920-1945). Türk Tarih Kurumu Yayınları, Ankara, 2000.

TANSEL, Selahattin, Mondros 'tan Mudanya'ya Kadar C.IV, Milli Eğitim Bakanlığı Yayınları, İstanbul, 1991.

TELLAL, Erel, "SSCB’yle İlişkiler”, Türk Dış Politikası, Ed. Baskın Oran, İletişim Yayınları, İstanbul, 2009, s. 314-324.

TOKER, Metin, Türkiye Üzerinde 1945 Kâbus, Akis Yayınları, Ankara, 1971.

UÇAROL, Rifat, Siyasi Tarih 1789-2014, Der Yayınları, İstanbul, 2015.

YILMAZ, Şuhnaz, "Challenging the Stereotypes: Turkish-American Relations in the Inter-War Era”, Middle Eastern Studies, s. 223-237, 2006.

YÜCEER, Saime, Milli Mücadele Yıllarında Ankara-Moskova İlişkileri, Sentez Yayınları, İstanbul, 2016.

\section{b. Resmi Yayınlar}

TBMM, Zabıt Ceridesi, 4. Dönem, 1. Yasama Y1l, Cilt 3. (22.7.1931).

TBMM, Zabıt Ceridesi, 5. Dönem, 2. Yasama Yı11, Cilt 7. (20.12.1935).

TBMM, Zabıt Ceridesi, 7. Dönem, 4. Yasama Y1lı, Cilt 201. (1.11.1945).

TBMM, Zabıt Ceridesi, 8. Dönem, 1. Yasama Yıl1, Cilt 1. (13.08.1946).

The Foreign Relations of the United States (FRUS), The Conferences at Cairo and Tahran 1943, Pre-Conference Papers. (1 November 1943).

The Foreign Relations of the United States (FRUS), The Conferences at Malta and Yalta, III. The Yalta Conference, February 4-5, 1945. (11 February 1945).

The Foreign Relations of the United States (FRUS), The Conference of Berlin (The Potsdam Conference), 1945, V. II. Final Documents. (2 Agust 1946).

\section{c. Süreli Yayınlar}

“Türkler, Sovyet ile Yapılacak Anlaşmanın Rusya'yı Müttefiklere Katılmaya Götürebileceğini Öngörüyor" The Evening Star, 22 Eylül 1939.

Dewitt Mackenzie “Avrupa'da Savaş”, The Evening Star, 26 Eylül 1939.

“Türkiye Yeni Rus Tekliflerini Reddetti”, The Key West Citizen, 18 Ekim 1939.

The Key West Citizen, 19 Ekim 1939.

“Türk Misyonu, Ekonomik-Askeri Anlaşmaları Londra'ya Götürdü”, The Evening Star, 1 Ekim 1939.

Dewitt Mackenzie, "Türkler Müttefiklerle Anlaşma İmzaladı", The Evening Star, 19 Ekim 1939.

Constantine Browne, "Türk Pakt1, Müttefikler ve ABD Silah Üreticileri İçin İyi Bir Haber Ancak Diktatörler İçin Kötü”, The Evening Star, 20 Ekim 1939.

“Rusya, Türkiye'yi Uyarıyor”, The Evening Star, 22 Ekim 1939.

\section{History Studies}


David Lloyd George, “Türkiye Belirleyici Faktör”, The Evening Star, 22 Ekim 1939.

“Türkiye Neden Önemli?”, The Evening Star, 27 Ekim 1939.

Joseph W. Labine, "Müttefikler, Nazi Havasına Türk Diplomatik Darbesiyle Karşı Koyabilir", The Midland Journal, 27 Ekim 1939.

Dorothy Thompson, "Kayıtta!", The Evening Star, 23 Şubat 1945.

“Türkiye, Almanya ve Japonya'ya BM İçin Savaş İlan Etti”, The Wilmington Morning Star, 24 Şubat 1945.

Joseph M. Levy, “Türkiye, San Fransisco Konferansında Koltuğunu Almak İçin Savaş İlan Etti”, The New York Times, 24 Şubat 1945.

Constantine Brown, "Değişen Dünya”, The Evening Star, 28 Şubat 1945.

“Kızıllar, Türk Anlaşmasının Geçersiz Olduğunu Açıladı”, The Wilmington Morning Star, 22 Mart 1945.

“Türklerin Öngördüğü İyileştirilmiş Sovyet Anlaşması”, The Evening Star, 22 Mart 1945.

Constantine Brown, "Değişen Dünya”, The Evening Star, 23 Mart 1945.

"Rus Siyaseti: Türkiye”, The Wilmington Morning Star, 6 Nisan 1945.

"Türkiye, Antlaşmanın Feshi Konusunda Kızıllarla Hemfikir; Yeni Dostluk Antlaşması Öneriyor", The Wilmington Morning Star, 9 Nisan 1945.^

Clifton Daniel “İngiltere, Rusya Hakkındaki Görüşlerini Pekiştiriyor”, The New York Times, 11 Mayıs 1945.

"Rusya-Türkiye Görüşmesi Planlandı", The Key West Citizen, 26 Haziran 1945.

Constantine Brown, "Değişen Dünya”, The Evening Star, 22 Haziran 1945.

“Türkiye, Çanakkale Boğazı'nın Değişmesini İsteyen Kızıl Raporundan Rahatsız”, The Evening Star, 27 Haziran 1945.

The Wilmington Morning Star, 12 Temmuz 1945.

Constantine Brown, "Rus-Türk Meselesi Üç Büyükleri Test Edecek”, The Evening Star, 15 Temmuz 1945.

"Türk Sorunu”, The Key West Citizen, 2 Ağustos 1945.

The Evening Star, 10 Ağustos 1945.

"Londra Konferans1”, The Evening Star, 11 Eylül 1945.

“Beş Büyükler, İtalya’yı Sömürgelere Dağıtabilir”, The Wilmington Morning Star, 16 Eylül 1945.

Constantine Brown, "Değişen Dünya”, The Evening Star, 15 Ekim 1945.

Constantine Brown, "Değişen Dünya”, The Evening Star, 27 Ekim 1945.

C.L.Sulzberger, “Müttefikler, Boğazlar Meselesine Çalışıyor”, 30 Ekim 1945.

“Amerika’nın Türkiye’ye Notası”, The New York Times, 1 Kasım 1945.

Garnett D. Horner, “ABD Sponsorları Çanakkale Boğazı Kullanımına Yönelik Kısıtlamaları Kaldırmayı Planlıyor", The Evening Star, 8 Kasım 1945. 
“Boğazlar Sorunu”, The Evening Star, 9 Kasım 1945.

"Boğazlar ile ilgili İngiliz Notası Türk Kabinesine Verildi”, The New York Times, 26 Kasım 1945.

Eddy Gilmore, "Rus Basını, Türkiye'nin Karadeniz Kıyısının 180 Milini Talep Ediyor", The Wilmington Morning Star, 21 Aralık 1945.

Bertram Benedict "Türkiye Talebi Piyon Gibi, Rusya Sınır Bölgelerine Hâkim Olmaya Kararlı", The Evening Star, 1 Ocak 1946.

“Rusya, Karadeniz Güçlerinin Kontrolünü İstedi”, The Evening Star, 13 Ocak 1946.

“Türk Başbakan, Sovyet Teklifini Kınadı”, The New York Times, 7 Ocak 1946.

Walter Lippmann, "Bugün ve Yarın”, The Wilmington Morning Star, 31 Ocak 1946.

Constantine Brown, "Değişen Dünya", The Evening Star, 3 Şubat 1946.

Constantine Brown, "Rusya Denize Ulaşmak İstiyor", The Evening Star, 10 Şubat 1946.

Walter Lippmann, "Bugün ve Yarın”, The Wilmington Morning Star, 20 Şubat 1946.

Constantine Brown, "Değişen Dünya”, The Evening Star, 21 Şubat 1946.

Constantine Brown, “Türk Problemi”, The Evening Star, 3 Mart 1946.

“Missouri Akdeniz Limanlarına Seyre Çıktı”, The Wilmington Morning Star, 7 Mart 1946.

“Byrnes, ABD’nin Sovyetlerin Türkiye Taleplerinden Az Bilgisi Olduğunu Açıkladı", The Evening Star, 9 Mart 1946.

"Rus Birlikleri, Tam Donanımlı, İran'ın Başkentine Yakın”, Henderson Daily Dispatch, 13 Mart 1946.

James B. Reston, "Amerika ve İngiltere Türk Topraklarına Yönelik Sovyet Talepleri Konusunda Bilgilendirildi”, The New York Times, 8 Mart 1946.

"Churchill, Sovyet'ten BM Güvenlik Konseyinin Sorunlarını Çözmesine İzin Vermesini İstedi”, The Evening Star, 16 Mart 1946.

"Sekiz Bakandan Truman'a Mektup", The Evening Star, 17 Mart 1946.

“Butler, Rusya'nın İran Petrolünü Alması ve Çanakkale’ye Girmesi Gerektiğini Söyledi”, The Evening Star, 25 Mart 1946.

"Rusya ve Barış", The Wilmington Morning Star, 19 Mart 1946.

Constantine Brown, "Değişen Dünya”, The Evening Star, 29 Mart 1946.

“Türkiye Ziyareti”, The New York Times, 12 Nisan 1946.

"Sovyetlerin, Türklerden Görüşme Talep Ettiği Bildirildi ”, The New York Times, 15 Nisan 1946.

Constantine Brown, "Değişen Dünya", The Evening Star, 14 Mayıs 1946.

J. M. Roberts, "Haber Yorumları", The Wilmington Morning Star, 7 Temmuz 1946.

George Fielding Eliot, "Güç Diplomasiyi Destekliyor”, The Evening Star, 6 Ağustos 1946.

“Rusya, Montreux Sözleşmesinin Gözden Geçirilmesini İstiyor”, The Evening Star, 11 Ağustos 1946.

\section{History Studies}


"Rusya, Çanakkale Boğazı'nın Karadeniz Güçlerince Kontrol Edilmesini İstedi”, The Evening Star, 13 Ağustos 1946.

H.R.Knickerbocker, "Yeni Türkiye Başbakanı, Orduyu Kızıllar İle İhtilaf Nedeniyle Harekete Geçirdi", The Evening Star, 11 Ağustos 1946.

Constantine Brown, "Değişen Dünya”, The Evening Star, 13 Ağustos 1946.

"Sovyetlerin Çanakkale Boğazı Taleplerinin Türkiye Tarafindan Reddedildiği Bildirildi”, The Evening Star, 14 Ağustos 1946.

“Türkiye Çanakkale Paktı'nı Değiştirmeye Hazır, Ancak Görüşme Talep Ediyor”, The Evening Star, 15 Ağustos 1946.

Constantine Brown, “Değişen Dünya”, The Evening Star, 15 ve 19 Ağustos 1946.

“Kız1l İddiasına Karşı Türkiye Güçlü Duruyor”, The Evening Star, 17 Ağustos 1946.

"Boğazlar İle İlgili Rus Talebi ABD Tarafından Reddedildi”, Henderson Daily Dispatch, 21 Ağustos 1946.

“Rusya'nın Çanakkale'nin Kontrolü Konusundaki Notasına Türkiye Yanıt Verdi”, Henderson Daily Dispatch, 22 Ağustos 1946.

"Sovyetler Birliği'nin Türkiye Taleplerine ABD Karşı Çıkıyor", The Wilmington Morning Star, 22 Ağustos 1946.

“Rusya ve Boğazlar”, The Evening Star, 22 Ağustos 1946.

“Çanakkale Durumu”, Henderson Daily Dispatch, 23 Ağustos 1946.

“Türkiye'nin Konumu”, The Evening Star, 25 Ağustos 1946.

"Ankara, Rusların Boğazlar Hakkındaki Korkularını Anlamada Zorluk Çekiyor", The Evening Star, 24 Ağustos 1946.

“Türkler, Sovyetlerin Çanakkale Boğazı'ndaki Payına Olan Talebini Açıkça Reddetti”, Henderson Daily Dispatch, 24 Ağustos 1946.

“Sonuncu Değil”, Henderson Daily Dispatch, 27 Ağustos 1946.

“Çanakkale Boğazı Tartışması Belirsizdir; Milletler Barıș İstiyor”, The Midland Journal, 30 Ağustos 1946.

"İngiliz, Amerikan ve Türk Filoları Ege Denizi'nde Birleşik Tatbikat Gerçekleştirecek", The Evening Star, 4 Eylül 1946.

"Savaş Gemileri ve Ziyaretler", The Key West Citizen, 13 Eylül 1946.

Walter Lippmann, "Sovyet Hükümeti, Sorunun Çözülmesi Gereken Yeri Açıkça Ortaya Koydu”, The Wilmington Morning Star, 6 Eylül 1946.

"Pepper, Boğazların Kullanımına Yönelik Sovyet Teklifini Savunuyor", The Evening Star, 8 Eylül 1946.

Drew Middleton, "Rusya, Türkleri, Boğazlar Konusunda Yabancı Yardımından Kaçmaları Konusunda Uyardı”, The New York Times, 29 Eylül 1946.

“Türk Uçakları Rusya'da Kayboldu”, The New York Times, 10 Eylül 1946. 
“Kızıllar, Çanakkale Boğazı Taleplerini Yeniliyor”, The Wilmington Morning Star, 29 Eylül 1946.

“Türkiye Ordusu, Kızıl Talebinden Sonra Alarma Geçti”, The Evening Star, 29 Eylül 1946.

"Ruslar İkili Oynuyor", The Wilmington Morning Star, 30 Eylül 1946.

Constantine Brown, "Değişen Dünya”, The Evening Star, 2 Ekim 1946.

Constantine Brown, "Türkler Herhangi Bir Rus Egemenliğini Engellemeye Kararlı", The Evening Star, 6 Ekim 1946.

“Türkiye'yi Tercih Ediyor”, The Key West Citizen, 10 Ekim 1946.

“ABD, Türkiye İle İlişkide Olan Rusya'ya Karşı Çıkıyor”, The Key West Citizen, 12 Ekim 1946.

Dorothy Thompson, The Evening Star, 16 Ekim 1946.

“Talepler Reddedildi”, The Wilmington Morning Star, 21 Ekim 1946.

“ABD Muhalefeti Yeniden Düzenlendi”, The Wilmington Morning Star, 12 Ekim 1946.

“Ruslar, ABD’nin Türklere 'Çarpık' Desteğini Görüyor”, The New York Times, 21 Ekim 1946.

"Çanakkale Boğazı İle İlgili Sovyet Talepleri Yine Reddedildi”, Henderson Daily Dispatch, 19 Ekim 1946

“ABD, Türklere 25-50 Milyon Kredi Sağladığını Bildirdi”, The Evening Star, 20 Ekim 1946.

Constantine Brown, "Değişen Dünya", The Evening Star, 21 Ekim 1946.

"Potsdam'1 Uygula Ya Da Yeni Anlaşma İmzala", The Evening Star, 22 Ekim 1946.

Constantine Brown, "Değișen Dünya”, The Evening Star, 22 Ekim 1946.

The Wilmington Morning Star, 26 Mart 1947.

“Türk-Sovyet Barıșı Mümkün”, The Wilmington Morning Star, 2 Kasım 1946.

“İngiltere, Boğazlar Paktı İmzalayıcılarını Konferansa Çağırıyor”, The Evening Star, 24 Aralık 1946.

Constantine Brown, "Stalin, İngilizlerle Geniş Bir Çözüme Hazır Olduğunu Bildirdi”, The Evening Star, 20 Şubat 1947.

The Wilmington Morning Star, 30 Mart 1947.

“Türkler Memnun”, The Evening Star, 13 Mart 1947.

"Türkiye, ABD Nakit Yardımını Ordusuna Kullanacak", The Wilmington Morning Star, 13 Mayıs 1947. 


\section{EKLER}

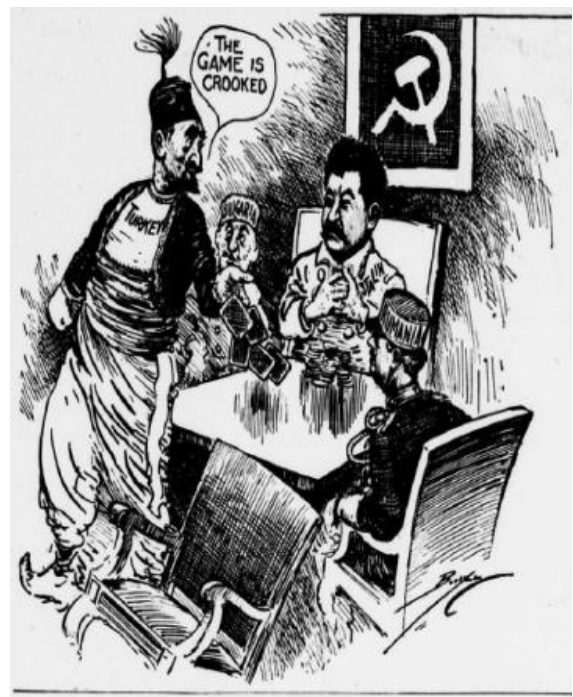

EK 1: The Evening Star, 19 Ekim 1939.

\section{Why Turkey Is Important-}

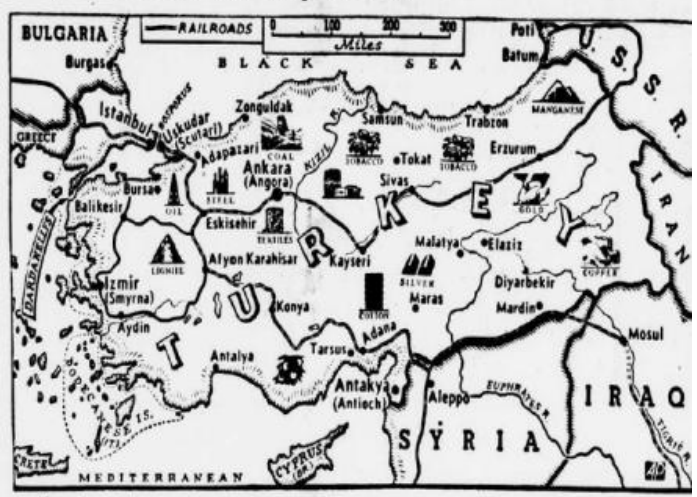

Map shows the material wealth of Turkey and her geographical position, geography being the №. 1 reason for her importance. Once the "sick man of Durope." Turkey today is regarded as hoiding a 172-mile-long key to Europe's balanee of power puzzle. That key is made up of the 35mile Dardanelles Strait, the 17-mile Bosporus Strait and the Sea of Marmora lying between them. It is the key to the Black Sea, to Russia, to Rumania. When Turkey signed mutual assist-
ance arreements with France and England, therefore, her act was noted as a check to Germany ance agreements with France and England, therefore, her act was noted as a check to Germany
and Russia. Turkej; also borders on Iran and Iraq, both under British infuence, both rich in oll

EK 2: The Evening Star, 27 Ekim 1939.
밥

HISTORY STUDIES 1488

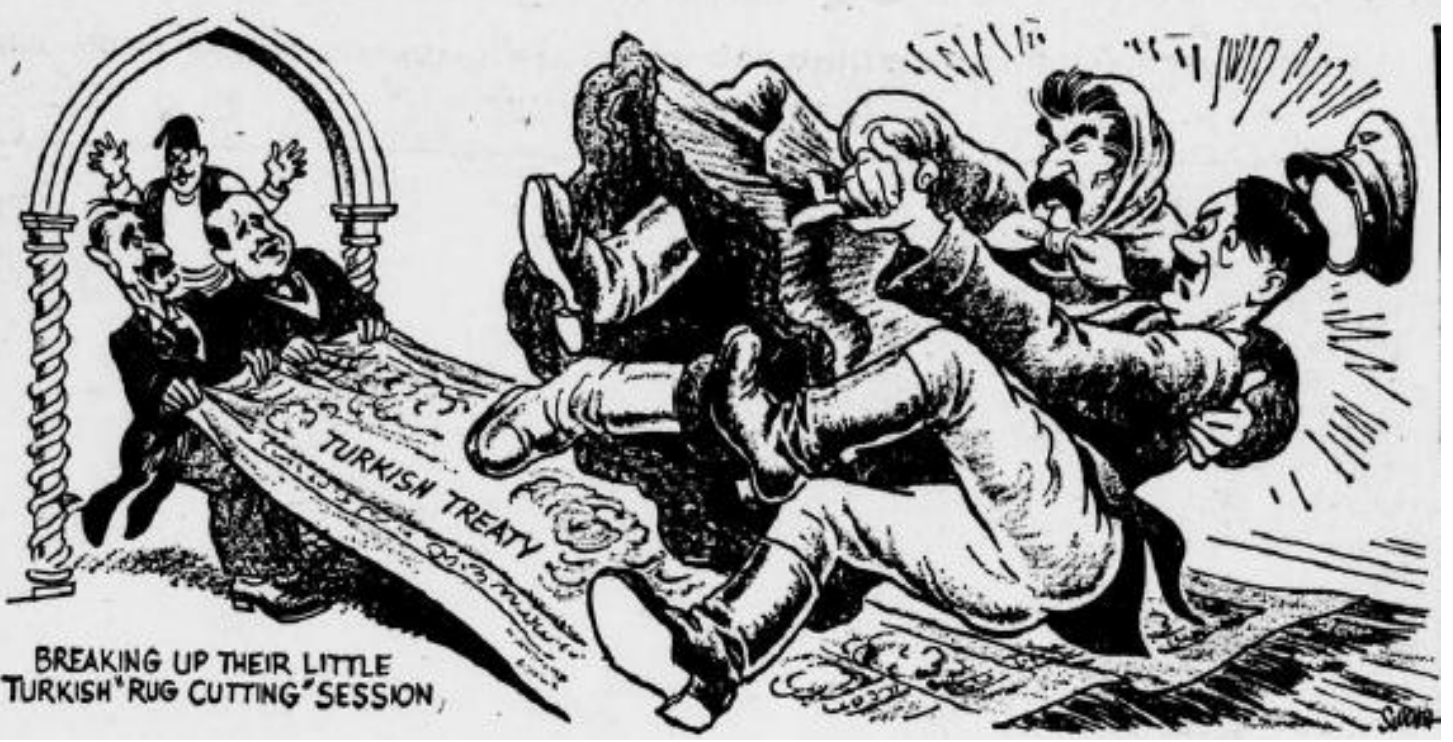

Volume 11

Issue 5

October

2019

EK 3: The Evening Star, 22 Ekim 1939. 


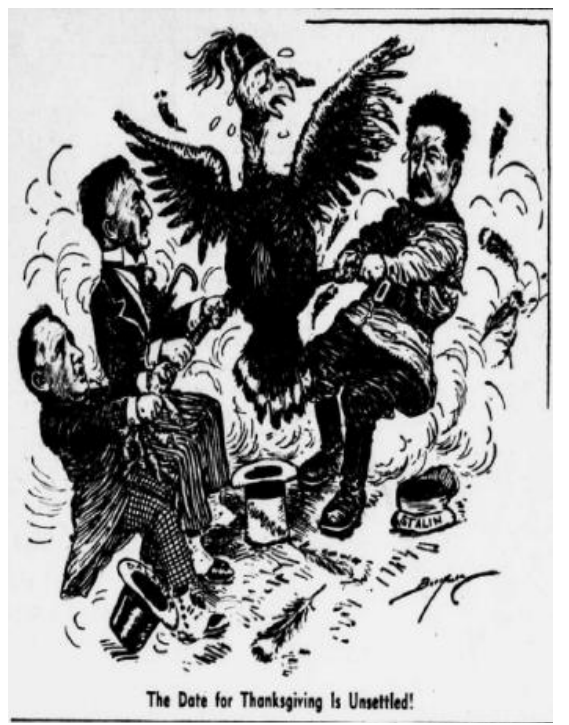

EK 4: The Evening Star, 1 Ekim 1939.

HISTORY

STUDIES

1489

Volume 11

Issue 5

October

2019

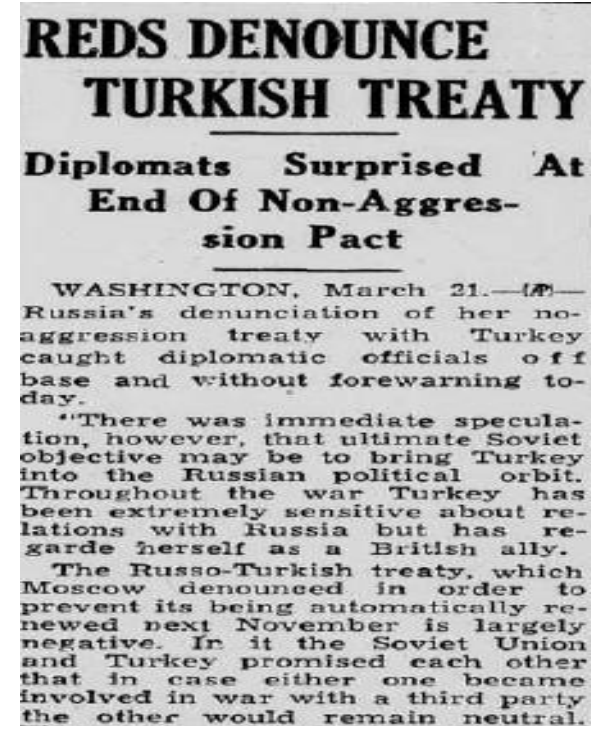

EK 5: The Wilmington Morning Star, 22 Mart 1946.

THE DARDANELLES SITUATION

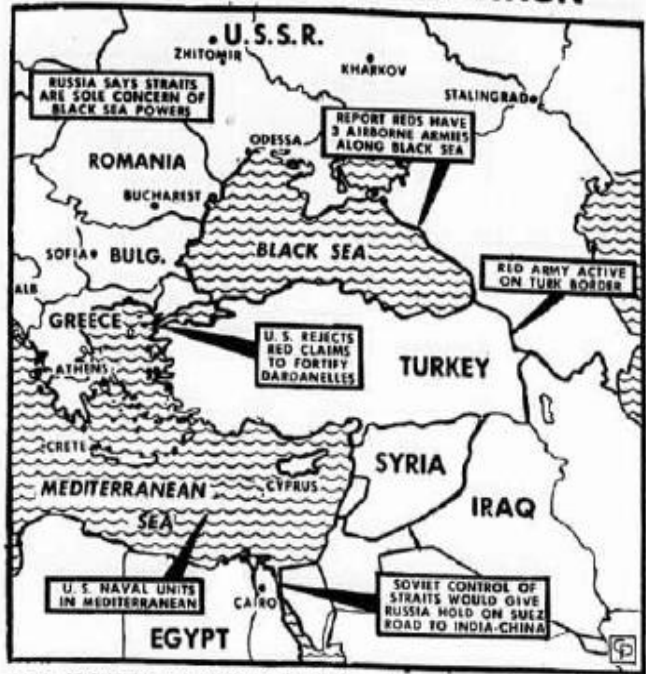

U. 5. REJECTION OF RUSSIAN CLAIMS to the right to fortify the vitai Dardanelles straits uncovers nnother teuse situation. As outllaed on the
matp, the Ameriena statement pointed out

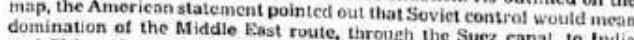
and China; that such fortifieation would eause Rusicz canal, to India and air power in Turkey and Norke Turkey a virtual to maintain land Recently Russia also insisted that the stralis a vitual satellite nation. sive concern of the Blacis Sen nower -Russia, Turkey Bulgaria and that she defend them jointly with Turkey. Thania and borne Red armies are repocd poised along the Bliek Sea All U.S. warships in Europe are concentrated in the Sleditertancen in the Unte areas. Among them is the carrier Franklin D. Roosetelt, international

EK 7: Henderson Daily Dispatch, 23 Ağustos

EK 6: The Wilmington Morning Star, 22 Ağustos 1946. 1946. 